\title{
A GREEN ECONOMY MODEL FOR INDIA: TECHNICAL SUMMARY OF METHODS AND DATA USED
}

\section{ABSTRACT}

As a signatory to the Paris Agreement, India has pledged to contribute to mitigating greenhouse gas emissions and building resilience against climate change. The country's nationally determined contribution, ${ }^{1}$ through emission reduction and augmentation of carbon sinks by 2030, demonstrates India's willingness to take climate action. The pathways for such action will be determined by the policy measures that the country adopts now and in the future.

The green economy model for India is a system dynamics model that has been customized to the national context in the structure of the model and input data. ${ }^{2}$ It also takes into account the key priorities for the country, incorporating primary and allied sectors affecting climate change at the national level. The model has been developed jointly by World Resources Institute India and KnowlEdge Srl (Switzerland); it is based on a Green Economy Model (GEM) published by Andrea M. Bassi (Bassi 2015). The GEM has also been used in other countries to explore low-carbon development pathways; the model is customized to the context in which it is applied. The model is intended to provide tools for making informed policy decisions that would take India to a low-carbon development pathway. This technical note focuses on the structure of the model, the motivation behind developing it, and the data and assumptions accompanying it.

\section{CONTENTS}

Abstract. .1

1. Introduction ............................................ 2

2. Model Structure ...........................................

3. Discussions and Way Forward ....................... 20

Appendix A: Economic and Sectoral indicators ......... 22

Appendix B: Data Sources and Gaps .................... 23

Endnotes .............................................. 29

References .............................................. 30

WRI Technical Notes document methodology underpinning research publications, interactive applications, and other tools.

Suggested Citation: Golechha, A., A. Raman, A. Srivastava, A. M. Bassi, and G. Pallaske. 2022. "A Green Economy Model for India: Technical Summary of Methods and Data Used.” Technical Note. Washington, DC: World Resources Institute. Available online at https://doi.org/10.46830/writn.21.00033. 


\section{INTRODUCTION}

The stabilization of greenhouse gas (GHG) emissions in the atmosphere involves commitments from various nations to curb their current and future emissions from human activity and improving the ability of populations to adapt to unavoidable impacts of climate change (IPCC 2018). The Paris Agreement in 2015 was an ambitious step in tackling climate change; 196 countries expressed their ambitions toward curbing climate change as well as taking steps toward adapting to a changing environment.

India is one of the signatories to the Paris Agreement and is contributing to strengthening the global response to climate change. To this end, India has submitted its nationally determined contributions (NDCs) to the United Nations Framework Convention on Climate Change (UNFCCC), under which India committed to reducing emissions intensity by $33-35$ percent by 2030 compared with 2005 levels (NRDC 2020). It also pledged to increase carbon sinks by $2.5-3.0$ billion tonnes of carbon dioxide $\left(\mathrm{tCO}_{2}\right)$ and increase renewable energy share capacity to 40 percent (Government of India 2018).

The physical science aspect of the IPCC's Sixth Assessment Report suggests that it is very unlikely that global warming can be limited to $1.5^{\circ} \mathrm{C}$ (IPCC 2021). The seriousness of the global warming situation clearly indicates the urgency of climate action. Among the biggest emitters in the world, India currently stands at the fourth position (United Nations Environment Programme 2020). As a developing economy, however, India's developmental challenges are dynamic and complex, and require a balanced approach to both development and climate action. The analysis of the Climate Action Tracker analysis estimates India's commitments to be compliant with a $2^{\circ} \mathrm{C}$ target based on the current and subsequent policy choices (Climate Analytics and New Climate Institute 2021; NRDC 2017; IPCC 2021) shows that the regional impacts of such warming on India will be unprecedented and the world, along with India, might have to adopt revised ambitions. This would entail shifting to lower-carbon development pathways as well as looking at policies that would increase countries' ambitions to mitigate climate change.
This technical note summarizes a tool that can be used to appraise various low-carbon policy options and support more informed decision-making. The note outlines the development and components of the green economy model for India (GEM-India), a system dynamics model tailored to the Indian context. The interrelationships between the various sectors are captured through causal loop diagrams (CLDs) and the underlying mathematical model, along with the data sources that formed the input for the model, are described. The model is intended to address limitations in current siloed approaches to analyzing policy choices and impacts, offering a more holistic representation of the economy and providing a means to identify, appraise, and pursue appropriate low-carbon development pathways for the country.

\subsection{Motivation for the Study}

The COVID-19 virus had infected more than 34 million people in India, with more than 450,000 deaths, by the end of October 2021 (Covid-19 India 2021). During the peak of the national lockdown in 2020, India's unemployment rate touched 27 percent, with more than 120 million people losing their jobs (Centre for Monitoring Indian Economy 2020). Wages in the informal sector fell by 23 percent (International Labour Organization 2020), and the economy is estimated to have contracted by 9.6 percent in the calendar year (United Nations 2021).

India has been among the world's faster-growing major economies (OECD 2021) and is a significant contributor to total global GHG emissions (ClimateWatch 2020). The ongoing economic recovery, in light of the pandemic and India's NDCs, has revealed India's vulnerabilities and inequalities as a country. The pandemic has also shown India's strength in adaptability and innovation-and highlighted the impact human activity has on the environment. This emphasizes the need to adopt sustainable development pathways that adequately consider the interlinkages between health, climate, and the economy.

Research demonstrates that such ambition for mitigating climate change is compatible with broader socioeconomic development objectives; the transition to a global 
low-carbon economy can deliver US $\$ 26$ trillion in economic benefits through 2030 and create 65 million new jobs (Pai et al. 2020). Although this also represents a valuable opportunity in India, it comes with challenges. For instance, the domestic solar power industry would have to grow to approximately 30 times its present size to absorb the jobs currently in the coal sector (Pai et al. 2020). Further, it is useful to note that the jobs created through "green" investments in, say, solar power are not in the same geographical location as-or would necessarily be equivalent in benefits and security to-the jobs lost in the fossil fuel sector, creating concerns about the justness of the economic transition and its subnational impacts.

There is, thus, a need to identify and evaluate policy packages that can

place India on a lower-carbon development pathway;

ensure continued economic growth;

create new jobs, ensuring a just and inclusive pattern of development; and

- deliver health and other developmental benefits and reduce vulnerabilities.

World Resources Institute (WRI) India, in partnership with Srl (Switzerland), has developed a methodological framework for climate and environmental policy analysis as it relates to inclusive economic development, resulting in the creation of a GEM for the Indian context. The GEM-India is an integrated model used for the appraisal of low-carbon, environmentally sustainable policies; it captures some of the complex relationships between socioeconomic variables and climate and environmental systems. In particular, it can shed light on the feedback loops, nonlinearities, and potential tradeoffs involved in the adoption of several policies and the policies'3 The GEM has been developed on the software platform VENSIM $^{\circledR}$, which also allows visual depiction of the relevant socioeconomic systems.
This technical note is intended to outline and support continued model development, and inform any parallel initiatives in the climate and economic modeling community. It will be periodically updated, as GEM-India is further developed.

The rest of this note is divided into two sections. Section 2 explains the structure of the model, using comparison with a few other contemporary models as well as explaining the assumptions and limitations of the GEM. The section lays down the systems diagram that the GEM is based on and the causal relations between variables. The section then moves on to the various sectors and interlinkages documented within the model as well as the pathways for change that help depict causality and impacts within the model. The depiction of externalities has also been documented, along with a comparison with contemporary models based on India, and the assumptions and limitations that the model operates within. Section 3 discusses the way forward for GEMIndia and how the model can be developed further.

\section{MODEL STRUCTURE}

The GEM-India model is a system dynamics model constructed based on India's policy priorities and economic, social, and environmental context. The model builds on a basic CLD that was constructed through the course of a consultative workshop with sector experts and modelers. The CLD is a visual representation of the prioritized variables, the factors that affect them, and the impacts these variables are responsible for. Figure 1 shows the CLD that underlies the GEM-India model.

The GEM-India model relies on data sources published by government reports and on data sets collected at the national level. The model uses time series data from 2000 to 2019 and relies on the input data to help produce the trends for key output variables (Appendix A). The input data (Appendix B) define the conditions for the different sectors that have been incorporated and will form the basis for constructing "what-if" scenarios. These scenarios are not a part of this technical note; they will be developed in later stages of work on the model. 
Figure 1 | Causal Loop Diagram Developed for GEM-India

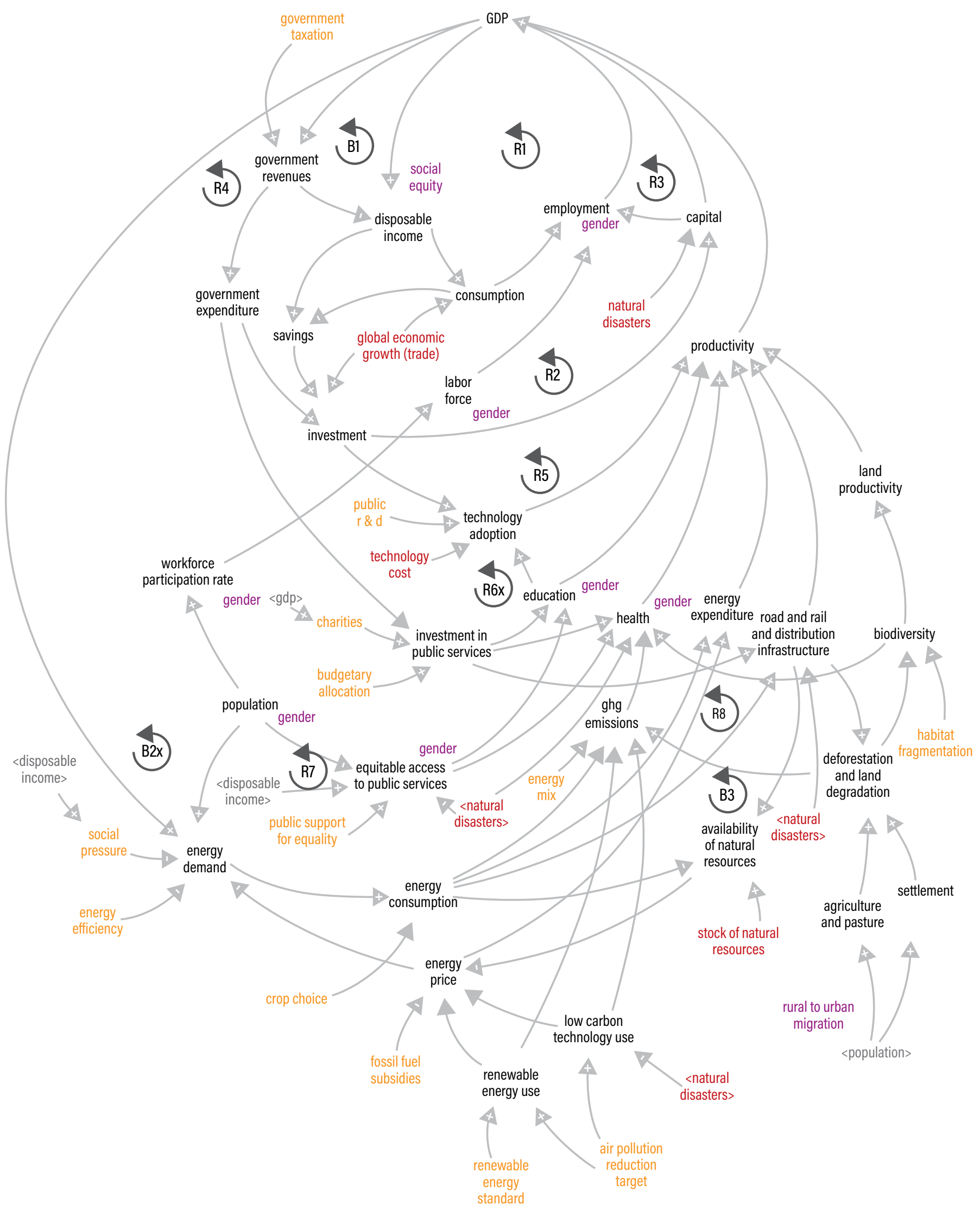

Notes: $\mathrm{GDP}=$ Gross Domestic Product, $\mathrm{GHG}=$ Greenhouse Gases, $\mathrm{B}^{* *}=$ Balancing Loops, $\mathrm{R}^{* *}=$ Reinforcing Loops.

Source: Authors. 
In general, the following color coding is applied in GEM:

Black: variables with a high degree of certainty and model calculations.

Red: external factors that either require additional validation or are based on assumptions that are not adjusted to the local country context.

- Orange: policy variables, which can be policy switches for activating policies, policy-related parameters, or parameters affected by policies that feed back into the model structure.

- Purple: subscripts or disaggregation represented within a variable.

Pink: variables indicating parameters and impacts related to Covid-19. There are only a few in the model; the pink color means they are more easily seen.

- Light blue: variables indicating either exogenous climate scenarios (see climate assumptions module) or variables related to climate impacts.

The model contains two main kinds of structures-reinforcing loops (R) and balancing loops (B). Reinforcing loops represent engines of growth and decay and push the system in one particular direction through a reinforcing cycle within the system. Balancing loops, on the other hand, resist the growth or decay of a system in one particular direction and seek equilibrium. They represent a regulating force within the model (Kim 1994). The feedback loops (R1) and (R2) illustrated in Figure 1 capture the impacts of investment, capital accumulation, and employment generation on the gross domestic product (GDP). An increase in GDP will cause an increase in government revenues and expenditure, along with disposable income and savings. This, in turn, increases overall investments, affecting capital and GDP and creating a feedback loop linking GDP and investments. Capital accumulates over time and contributes to economic growth, while at the same time generating additional employment, which further increases the beneficial impact on productivity and growth. This dynamic is reinforced by the beneficial impacts of economic growth on household income and consumption $\left(\mathrm{R}_{3}\right)$. An increase in GDP causes total disposable income to grow, increasing both consumption and tax revenues and generating additional jobs in the economy. Those jobs contribute to economic growth. The impact of increased taxation on disposable income is captured by the balancing loop (B1). As taxation increases, disposable income declines, causing consumption and related employment generation to decline as well. Increased taxation thus has a negative impact on employment generation and economic growth. On the other hand, as indicated above, higher taxation results in a higher public budget, which, through different channels, can also create jobs and stimulate the economy (R4).

More specifically, the (R4) loop captures multiple reinforcing loops that support beneficial impacts of government spending on productivity and stimulate economic growth and development. These beneficial impacts include

increased investments in education and health care as a result of increased government revenues;

- improvements in access to public services as a result of higher disposable incomes;

- expansion of infrastructure (power generation, roads, etc.) following an increase in investment in public services; and

- increased technology adoption by supporting R\&D and reducing technology costs.

In addition to these effects, GEM-India also captures the impacts of energy costs and energy-related emissions. Economic growth is sensitive to the effect of energy costs. If the cost of energy increases, economic growth would be curbed when compared with a scenario with cheap energy. The balancing loop (B2) captures the impact of energy demand on total factor productivity ${ }^{4}$ through GHG emissions and health, thereby reducing overall productivity and negatively affecting GDP. The impacts of emissions on total factor productivity ${ }^{4}$ are illustrated by the balancing loop (B3). Higher economic growth increases energy demand and energy consumption-related emissions. In addition to the GHG emissions, energy use causes air pollution through particle and other emissions, with adverse impacts on human health. As the concentration of pollutants increases, 
more people are prone to contracting respiratory diseases, which reduces productivity and increases health care expenditures.

The model represented in Figure 1 illustrates the basic structure of the full model that WRI India and KnowlEdge Srl are developing. The current model incorporates the relationships illustrated in Figure 1 in a more detailed manner. A simplified version of the model has been represented in the next section. Subsequent sections expand on the model structure further.

\subsection{Sectors, Variables, and Interlinkages}

India's policy priorities focus on supporting its development trajectory while reducing emissions intensity through shifts to renewable sources of energy, increases in energy efficiency, and various low-carbon shifts in transport, industry, agriculture, and land use. The next subsection depicts the causes and effects of changes in certain key variables. The current model has been constructed using more than 40 modules, each of which represents a different part of the model, grouped as follows:

Climate assumptions (climate scenarios through representative concentration pathways [RCPs] $2.6,4.5,6$, and 8.5)

- Population and poverty (births and deaths [by gender], labor income, and income distribution)

- Macroeconomic modules (GDP, demography, industry, services, agriculture, and employment, as well as government accounts)
Infrastructure and public services (roads, railways, irrigation, health care, and education)

- Agriculture and land use (forests, land use, land use change, and forestry [LULUCF], crop production, livestock, fertilizer application, irrigation, and water and land related to agriculture)

- Energy (demand, costs, and power generation, including employment)

- Emissions (GHG emissions and air pollutants from various sources)

Key outputs and policy assumptions

Figure 2 represents these modules in a simplistic, graphic manner; it does not represent the full scale of feedback loops present within the model, but it is an illustration of the major interlinkages that the model relies on. The economy is, as the model posits, the driving force behind growth, investment (government and private), and production. The economy is linked to infrastructure and to energy as well as emissions, which are key outputs. In the subsequent sections, the economy module and its linkages with some of the modules mentioned earlier will be discussed in further detail. That discussion will help explain these feedback loops and how they create pathways for change within GEM-India. 
Figure 2 | Simplified Graphic Representation of GEM-India

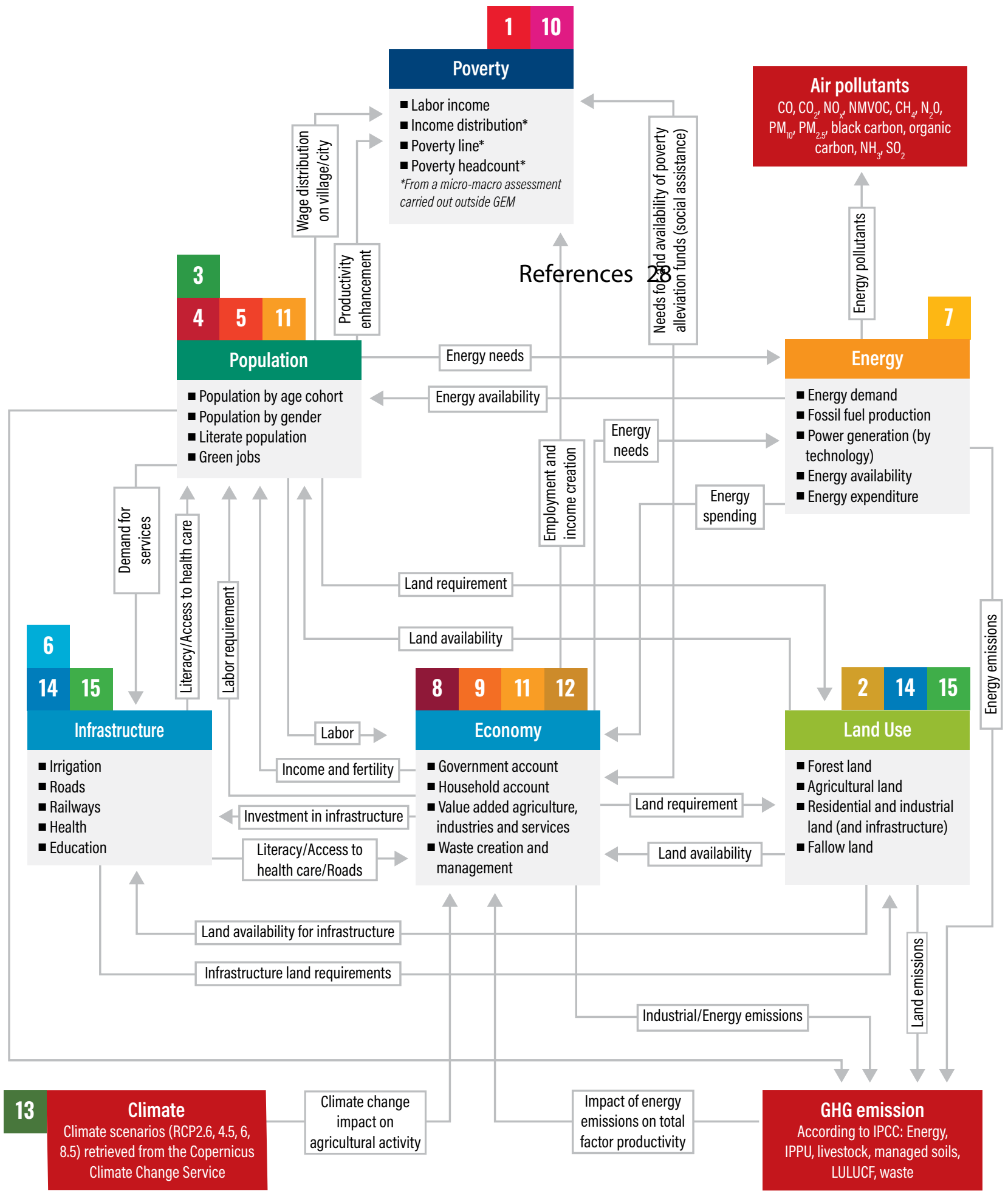

Notes; $\mathrm{CO}=$ carbon monoxide; $\mathrm{CO}_{2}=$ carbon dioxide; $\mathrm{NO}_{x}=$ nitrogen oxides; $\mathrm{NMVOC}=$ nonmethane volatile organic compounds; $\mathrm{CH}_{4}=$ methane; $\mathrm{N}_{2} \mathrm{O}=$ nitrogen dioxide; $\mathrm{PM}_{10}=$ particulate matter; $\mathrm{PM}_{2.5}$ = fine particulate matter; $\mathrm{NH}_{3}=$ ammonia; $\mathrm{SO}_{2}=$ sulfur dioxide; $\mathrm{RCP}=$ representative concentration pathway; IPCC = Intergovernmental Panel on Climate Change; IPPU = industrial processes and product use; LULUCF = land use, land use change, and forestry. The numbers shown in the figure refer to SDG goals and have been color coded to follow their respective icons per UN branding guidelines.

Source: Authors. 


\subsubsection{Pathways of Change: GDP and Emissions}

The model represents GDP as a function of agriculture, industry, and service sector production. The so-called real GDP agriculture sector, in turn, includes GDP from forestry and fisheries and crops as well as livestock. The real GDP industry and real GDP services are derived using past data for GDP, capital and labor elasticity, relative employment, and total factor productivity. The factor productivity, on the other hand, depends on total carbon dioxide equivalent $\left(\mathrm{CO}_{2} \mathrm{e}\right)$ emissions, the energy bill, health care, literacy rate, infrastructure, and technology (Figure 3). The causal relationships leading to total factor productivity in the industry sector and the causal linkages for total factor productivity in the services sector are similar.

This provides the basis for linking GDP to various modules such as agriculture, industry, and energy, as well as emissions.

As a tool to appraise low-carbon development policies, the GEM-India focuses on the economy and the environment, so it includes subsystems such as emissions, energy, fuel use, land use, and so on. The output of the emissions module is represented by the following equation representing by the sum of $\mathrm{CO}_{2}$ e emissions from energy, industry, livestock, soils, land, and waste.

\section{Equation 1: Formula for the calculation of total $\mathrm{CO}_{2}$ e emissions}

total annual $\mathrm{CO}_{2}$ e emissions (tonnes/year)

= total $\mathrm{CO}_{2}$ e emissions from energy

$+\mathrm{CO}_{2}$ e emissions from industry

+ total $\mathrm{CO}_{2}$ e emissions from livestock

$+\mathrm{CO}_{2}$ e emissions from land

$+\mathrm{CO}_{2}$ e emissions from managed soils

+ total $\mathrm{CO}_{2}$ e emissions from waste

Each of the emission factors from the different sectors has different underlying drivers. For instance, emissions from the industry sector depend on the real GDP from the industry sector, a GDP-emission factor (for the industry sector), ${ }^{5}$ the impact of improved processes on emissions, and time as shown in Figure $4 .{ }^{6}$

\section{Figure 3 | Causal Relationships Leading to Total Factor Productivity (Industry Sector)}

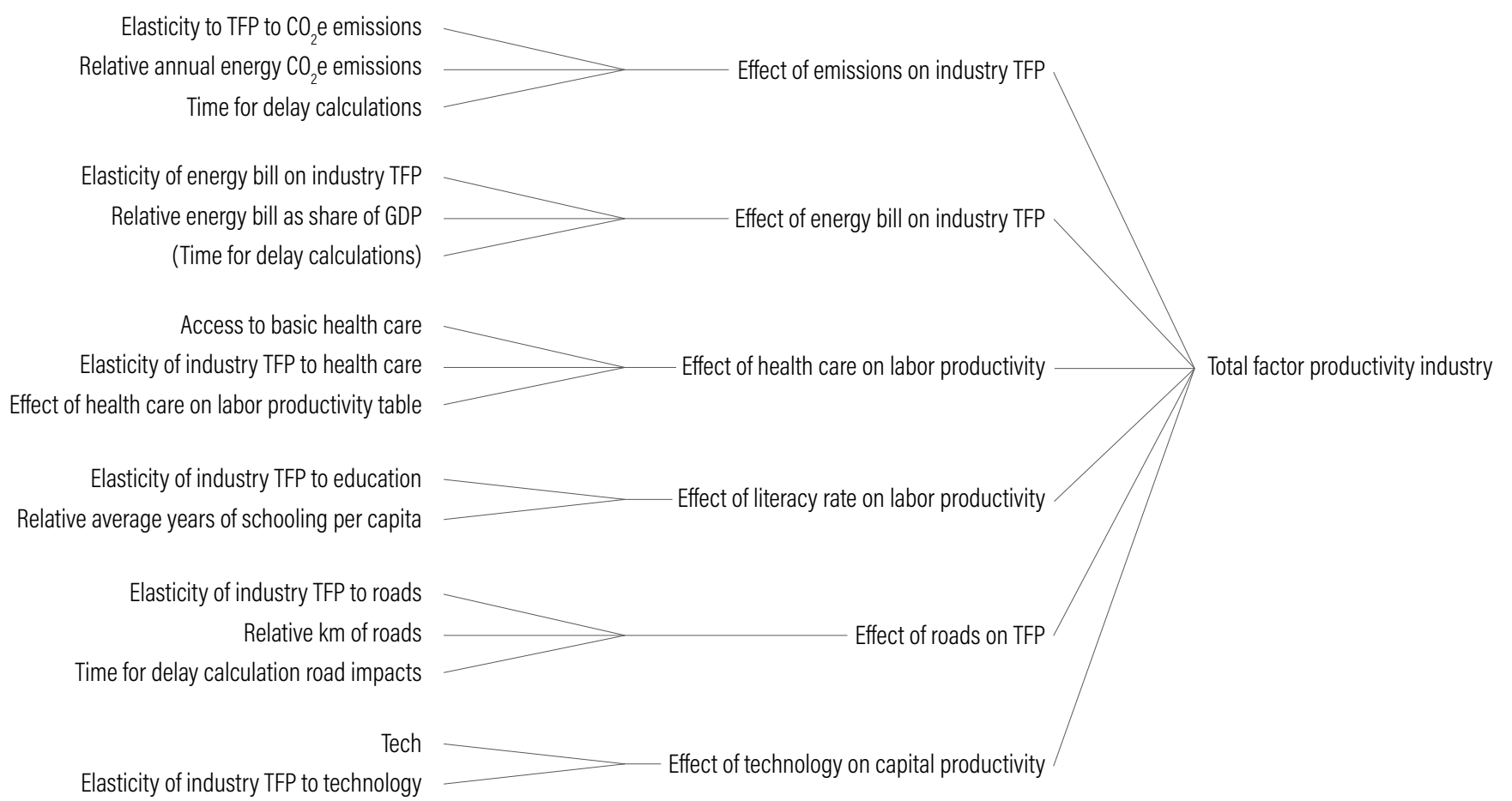

Notes: $\mathrm{CO}_{2} \mathrm{e}=$ carbon dioxide equivalent; TFP = total factor productivity; GDP = gross domestic product; $\mathrm{km}=$ kilometers.

These are outputs from the model. The software allows for parts of the model to be viewed in relation to what these variables impact and/or what causes them.

Source: Authors. 


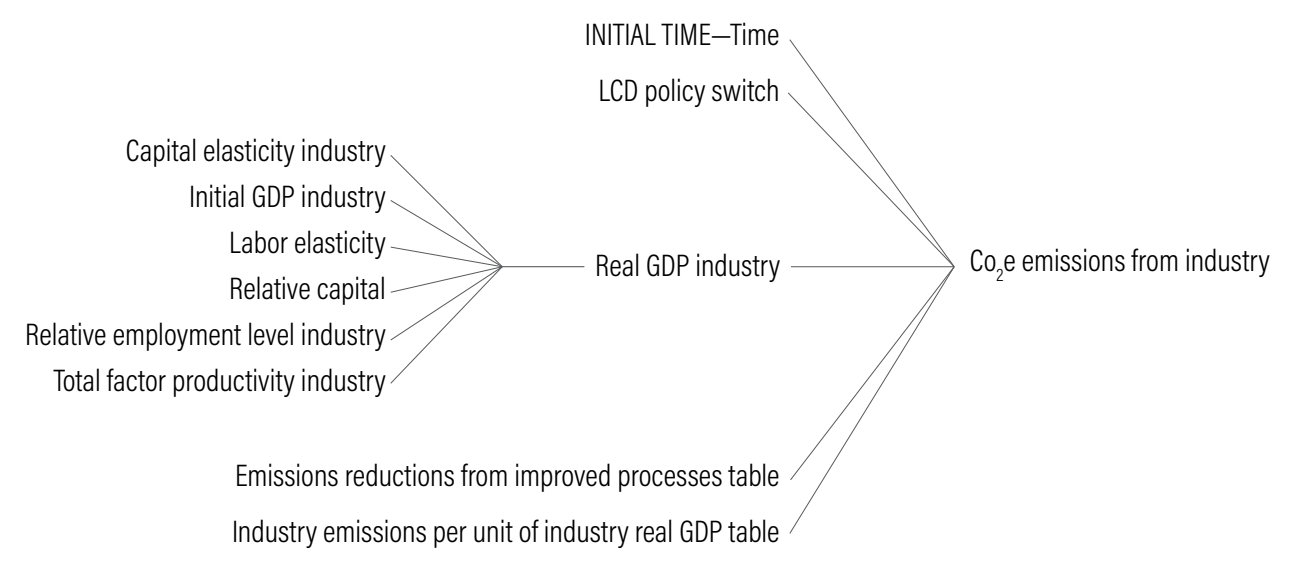

Notes: $L C D=$ low-carbon development; $G \mathrm{GP}=$ gross domestic product.

Source: Authors.

The emissions from the energy sector include emissions from the combustion of coal, petroleum and natural gas, biofuels, and waste (and also considers emissions from the use of fossil fuels for power generation). However, in the case of other GHGs, conversion factors from other gases, such as nitrous oxide $\left(\mathrm{N}_{2} \mathrm{O}\right)$ to $\mathrm{CO}_{2} \mathrm{e}$, are also considered, as is the case with GHG emissions from soils (Equation 2).

\section{Equation 2: Formula for the calculation of total $\mathrm{CO}_{2}$ e emissions from energy}

total $\mathrm{CO}_{2}$ e emissions from energy

$=($ SUM $($ coal emissions [sector!])

+ SUM (electricity emissions[sector!])

+ SUM (natural gas emissions[sector!])

+ SUM (petroleum emissions[sector!])

+ SUM (biofuels and waste emissions[sector!]))
The total emissions calculation also considers the emissions from land, livestock, and waste. This forms the connection between the emissions modules and the sectoral modules. The land use module is connected with the emissions module through the different types of land categories, with the agriculture sector through fertilizer application, with livestock through the type of livestock being reared, and with waste through the kind of treatment it is subjected to. The energy sector is represented through fuel demand and consumption which, in turn, lead to emissions. The causality behind emissions and the variables it depends upon are shown in Figure 5. 
Figure 5 | Causal Tree for Total Annual $\mathrm{CO}_{2} \mathrm{e}$ Emissions

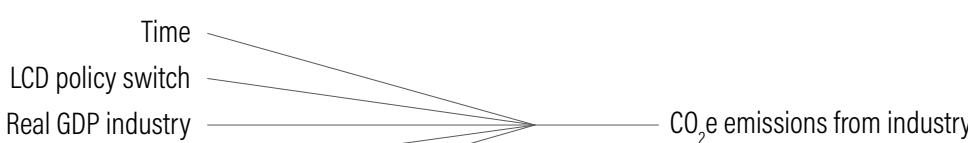

Emission reduction from improved processes table Industry emissions per unit of industry real GDP table

Emissions from agriculture land

Emissions from fallow land

Emissions from forest land

(2)

e emissions from industry

missions from settlement land

$\mathrm{CO}_{2}$ emissions from urea and limestone

$\mathrm{Kg}$ per ton

$\mathrm{N}_{2} \mathrm{O}$ to $\mathrm{CO}$

Total $\mathrm{N}_{2} \mathrm{O}$ emissions from managed soils

Unit correction for $\mathrm{N}_{2} \mathrm{O}$

ssions from managed soils

Biofuels and waste emissions

Coal emissions

Electricity emissions

Natural gas emissions

Petroleum emissions

$\mathrm{CO}_{2}$ e emissions from manure management

Total $\mathrm{CO}_{2}$ e emissions from livestock $\mathrm{CH}_{4}$

Total $\mathrm{C}_{2}$ e emissions from livestock

$\mathrm{CO}_{2}$ e emissions from wastewater

Total $\mathrm{CO}_{2}$ e emissions from MSW

$\mathrm{CO}_{2}$ e emissions from land

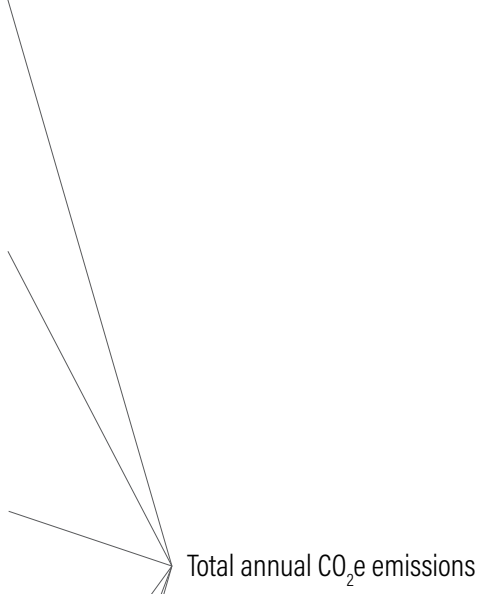

Notes; $\mathrm{LCD}=$ low-carbon development; $\mathrm{GDP}=$ gross domestic product; $\mathrm{CO}_{2}=$ carbon dioxide; $\mathrm{CO}_{2} \mathrm{e}=$ carbon dioxide equivalent; $\mathrm{N}_{2} \mathrm{O}=$ nitrogen dioxide; $\mathrm{CH}_{4}=$ methane; MSW = Municipal Solid Waste.

Source; Authors 
GEM-India has various key output variables (Appendix A) that have been generated through model runs based on the input data for various sectors. They are represented as:

Real GDP: This includes measures for total real GDP, GDP growth rate, and the real GDP for agriculture, industry, and services (Figure 6).

- Emissions: This includes total $\mathrm{CO}_{2}$ e emissions, as well as total $\mathrm{CO}_{2}$ e emissions from sectors such as energy, industry, livestock, managed soils, waste, and land (Figure 3).

- Employment: Mapped like GDP, this includes total employment in the economy as well as in the sectors of industry, agriculture, and services. (It follows the
; same structure as Figure 6 for GDP.) Green jobs are also estimated for each low-carbon intervention option, and a distinction is made between construction and operation and maintenance jobs for infrastructure (e.g., power generation).

- Energy demand: This is represented using the total normalized energy demand (Figure 7 and Figure 8) and the total demand of the different types of fuel, by sector. (The other fuel sources have a similar causal structure.)

Land use: Includes the distribution of total land into forest, settlement, forest, and agriculture land.

\section{Figure 6 | Causal Tree Representing the Relationships Leading to the Calculation of Total Real GDP}

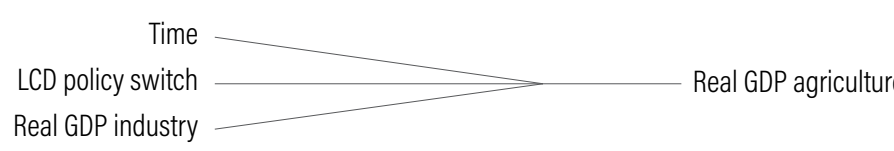

Emissions from agriculture land
Emissions from fallow land

Emissions from forest land

Emissions from settlement land

Emissions from settlement land

Emissions from settlement land

Emissions from agriculture land

Emissions from fallow land

Emissions from forest land

Emissions from settlement land

然

Emissions from settlement land

Note: GDP = gross domestic product; LCD = Low Carbon Development.

Source: Authors

Figure 7 | Causal Tree for Total Normalized Energy Demand

Normalized biofuels and waste demand - Total country normalized biofuels and waste demand Normalized coal demand - Total country normalized coal demand Normalized electricity demand - Total country normalized electricity demand

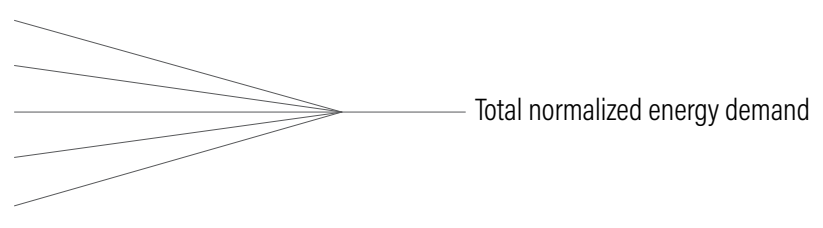

Source: Authors 


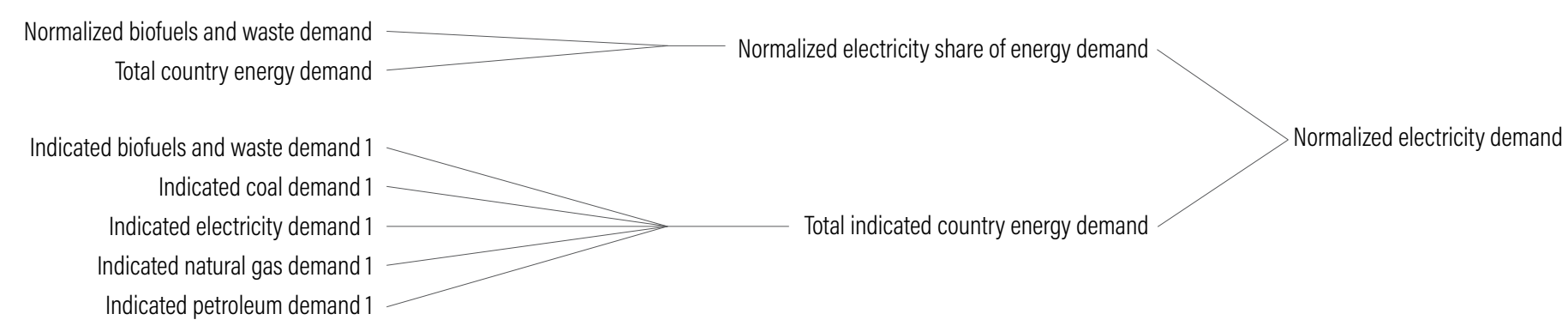

Source: Authors.

The values of these output variables are governed through policy switches, or levers, that help set the base conditions for the adoption of policies in various sectors. The model allows flexibility to build in these levers as exogenous effects (man-made decisions) over the model variables in any of the modules. The model also allows the same lever to be replicated in multiple modules and thereby shows how a single policy can have impacts across multiple sectors. For instance, the reforestation policy lever has an impact on both land use and emissions.

At the current stage of development, GEM-India has policy levers on sustainable agriculture, livestock, reforestation, energy efficiency, power generation, technology growth, waste management, industrial processes and product use (IPPU), emissions intensity, and fuel switching. The levers under fuel switching affect both the transport sector and the energy sector; energy efficiency affects the emissions and energy sectors. The policy levers that have been included in GEM-India are

sustainable agriculture: this sector includes the share of organic agricultural land, additional production from sustainable agriculture, and employment from sustainable cropland;

livestock: this sector includes the use of green and concentrated fodder and "overall emission reduction potential;

- forests: this sector includes reforestation and afforestation as a policy lever;

- energy efficiency: this is represented through an aggregate policy lever, additional energy efficiency improvements;

power generation: the policy levers under this category represent the electricity generation shares from various fuel sources; fuel switching: this category looks at the substitution effects where energy demand shifts from one fuel to another and includes the levers' share of biomass demand shifted to petroleum, and share of coal [and] petroleum electrified;

IPPU emissions: this reflects the emission reduction from process improvements;

- waste management: this includes policy levers that affect the "share of MSW [municipal solid waste] collected and share of waste used for energy recovery"; and

technology growth: this has been represented at an aggregate level as additional technology growth rate.

These policy levers will be supported using assumptions that will be developed at a subsequent stage in the study. The levers are, therefore, multisectoral and can have impacts across several iterations of the model, either through the incorporation of time lags or through indirect and induced changes that arise not from direct links but from reinforcing and balancing feedback loops and shadow variables ${ }^{7}$ within the model. This flexibility simplifies the way the impacts of certain policy choices are ascertained and therefore makes clearer which policy options will most likely help in reaching the goals initially set by national priorities.

\subsubsection{Pathways of Change: Employment, Government Accounts, and Public Services}

GEM-India goes beyond energy-emission models in considering variables and sectors that are not generally considered in the construction of such models. It considers variables such as employment and social sectors such as health and education over the years 2000-2050. 


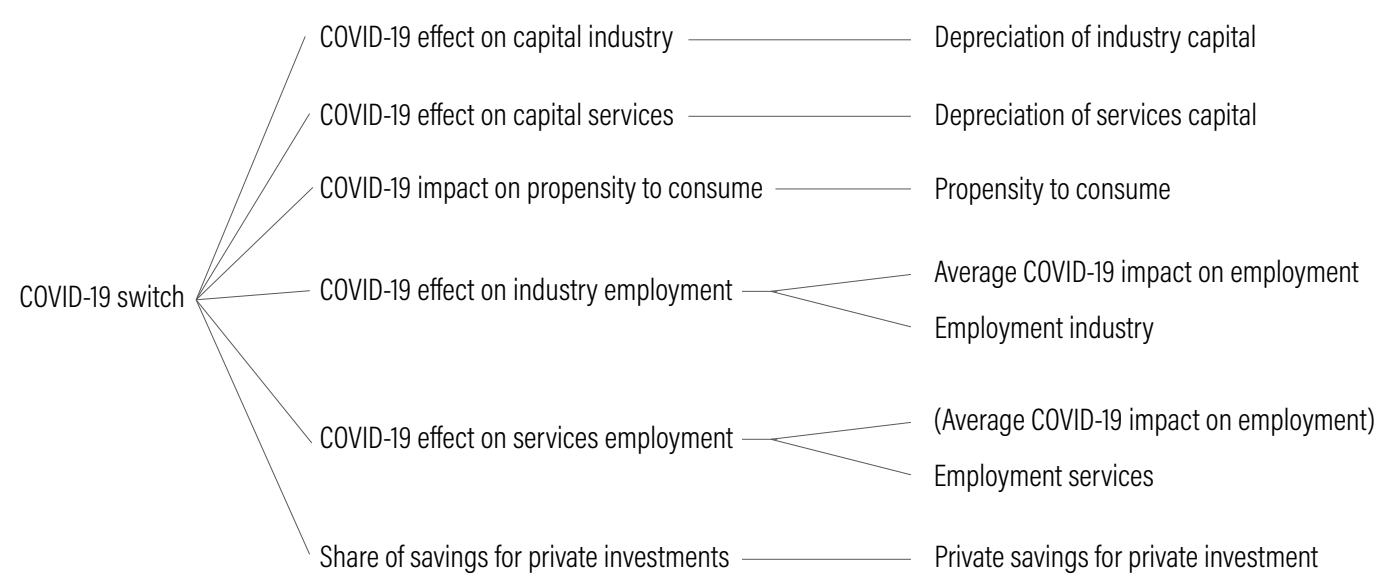

Source: Authors,

Figure 10 | Causal Tree for Employment

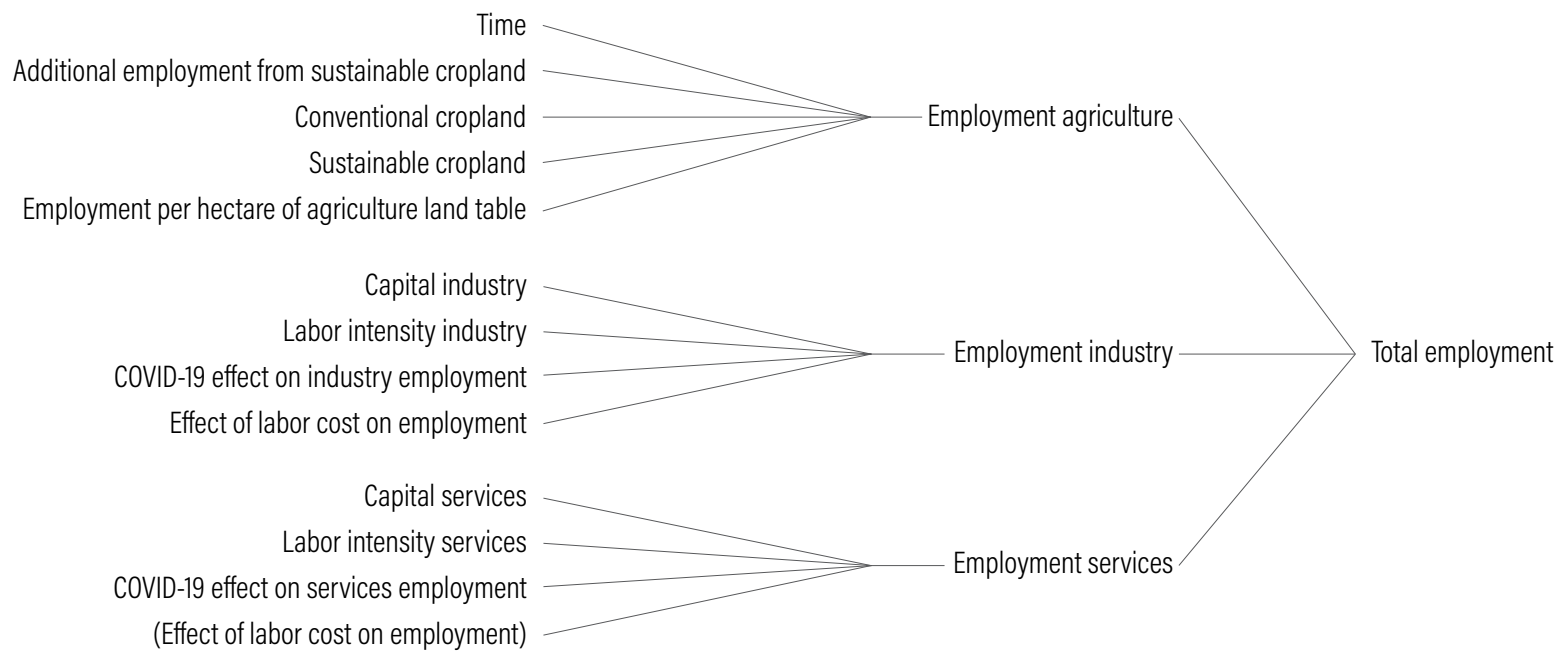

Source: Authors,

Employment is primarily represented in a manner similar to GDP, being a function of employment in the industry, services, and agriculture sectors. However, the employment in various sectors depends on factors such as labor cost and labor and capital intensity for the industry and services sectors (Figure 9). The model also considers the impact of COVID-19 on employment, as an example of how to incorporate the effects of suddenonset events in the model through employment and GDP. The COVID-19 effect reduces production, thereby reducing the use of capital and labor, increasing depreciation and unemployment and affecting the real GDP from the industry and services sectors.
In the agriculture sector, the model posits that employment is dependent on the per hectare employment potential and the types of croplands (conventional or sustainable). The energy sector also includes employment in terms of the construction of power generation capacity as well as operation and maintenance of that capacity. The impacts of employment depicted in the model are given in Figure 10.

These factors show how employment is related to the agriculture, industry, and services sectors. However, employment is also, indirectly, dependent on government spending as well as on domestic revenue to the government through taxes and grants. The government spending in the model is, in turn, dependent on the 
Figure 11 | Impacts of Government Investment

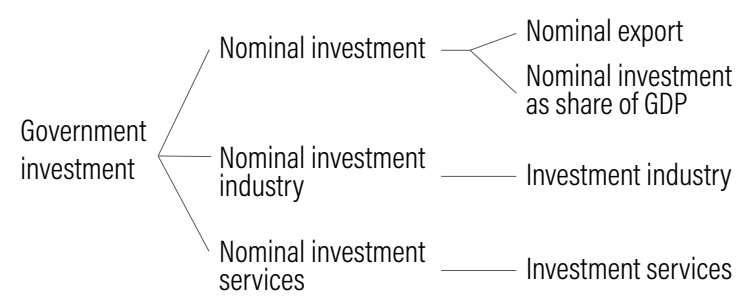

Note: GDP = gross domestic product.

Source: Authors

existing and the target deficit (which may be negative, based on the state of the economy) as well as domestic revenue. The government's spending and investments flow into the industry and services sectors, creating a reinforcing loop that affects GDP from these sectors. The impacts of government investment are shown in Figure 11.

Another essential aspect of investment comes from the private sector; this is a function of private savings, government financing in the private sector, and disposable income. The impacts of private investment are given in
Figure 12. The diagram represents how nominal investment is related to different aspects that make up GDP, such as investments in industry, services, and so on.

Public services include the health and education sectors as well as their relationship with total factor productivity and thereby GDP. From the perspective of government spending, the health sector is represented as a function of health centers' operating cost as well as of the capital expenditure for setting up the health centers. The model also incorporates the condition of disruption of health services as a possible impact on the health sector. Variables such as access to health care and areas covered by health care have been included within the model and interact with demography to define access. The education sector module includes enrollment, survival (or dropout), completion, and gender parity in the model and is dependent on population and time (the time it takes to transition from one cohort, or class, to the next) as well. ${ }^{8}$ In relation to total factor productivity, the variables of relevance include access to health care and average years of schooling per capita. The impact of education on labor productivity is shown in Figure 13.

Figure 12 | Impacts of Private Investment

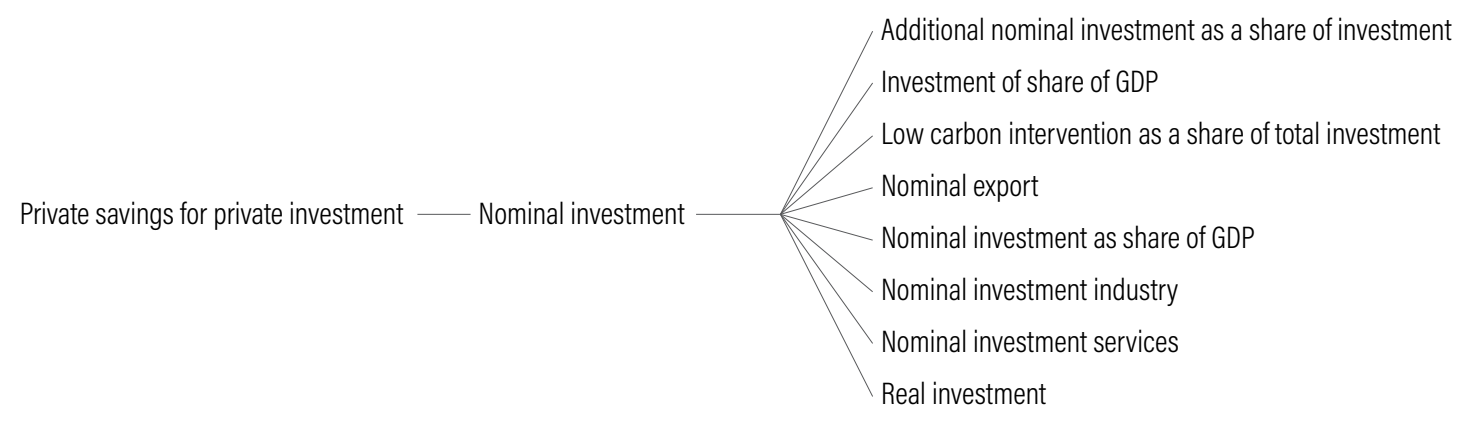

Note: GDP = gross domestic product.

Source: Authors 
Figure 13 | Impacts of Education on Total Factor Productivity

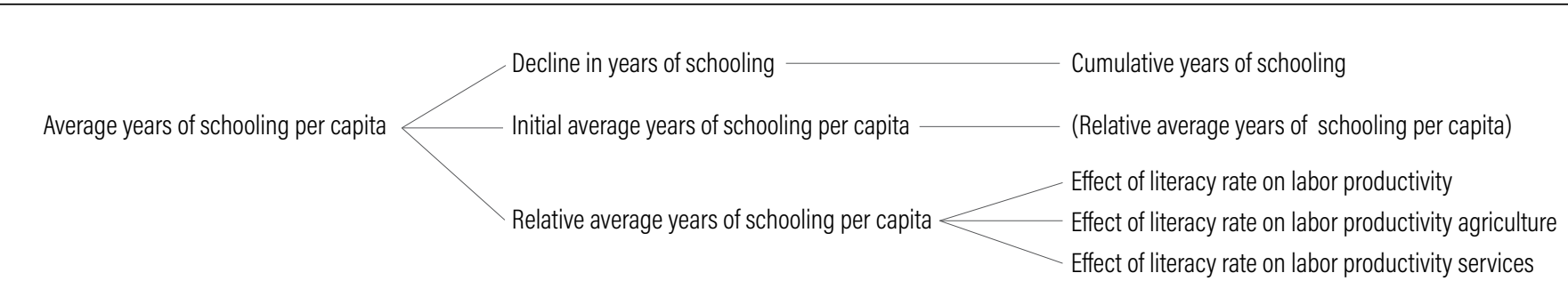

Source: Authors.

\subsubsection{Pathways of Change: Depiction of Externalities}

The GEM-India spans several sectors and incorporates multiple interlinkages that represent causes and effects within various systems. These variables have been represented in the form of stocks, flows, constants, and other auxiliary variables which represent policy variables, input variables and output variables. ${ }^{9}$ Externalities are represented as output indicators that have been added to GEM. Externalities are regarded as unintended consequences of investments that do not affect investors and so are usually not accounted for in economic and financial assessments. In some instances, externalities feed back into the macroeconomic production modules. Externalities are, in general, estimated based on biophysical flows, such as tonnes of $\mathrm{CO}_{2} \mathrm{e}$ emissions or tonnes of air pollutants. The $\mathrm{CO}_{2}$ e emissions and other pollutants allow estimation of the cost of climate change (social costs of carbon) and health (cost of respiratory diseases). These are classified as externalities because their impact on GDP through total factor productivity and further impact of GDP through the social cost of carbon happen outside the emissions subsystem in an indirect or induced manner. Table 1 lists the externalities considered in GEM-India.

There is a range of variables that affect multiple modules that do not constitute an externality. For example, real GDP affects modules such as government revenues, household accounts, energy demand, and others. However, there are externalities in the model that affect multiple modules, such as, for example, GHG emissions
Table 1 | Externalities in GEMI-India and Their Data Sources

\section{NAME OF VARIABLE}

TYPE

\begin{tabular}{ll}
\hline Social costs of carbon & Constant \\
\hline $\begin{array}{l}\text { Air pollutants per TJ of energy used for power } \\
\text { generation }\end{array}$ & Constant \\
\hline Air pollutants per TJ of final energy consumption & Constant \\
\hline GHG emissions from various fuel sources & Output \\
\hline
\end{tabular}

Note: $\mathrm{TJ}$ = terajoule; $\mathrm{GHG}=$ greenhouse gas.

Sources: Based on Ricke et al. (2019); Nordhaus (2017); and SEl (2021). GHG emissions were calculated within the model.

from energy, which affect total $\mathrm{CO}_{2}$ e emissions, energy costs (in the case of carbon taxation), and total factor productivity (via the social costs of carbon, or of air pollution) in the industry and services sector.

For instance, additional reforestation and afforestation affect land use while also creating additional carbon sinks, thereby reducing emissions. Similar variables have been used throughout the model. The risk with externalities becomes the challenge of double counting, which entails restricting the analysis to include only real benefits and costs. The likely error is to consider price externalities as an additional impact (Goldin 1975). ${ }^{10}$

Figure 14 | Indirect Relationship Linking Energy Bill to Total Factor Productivity

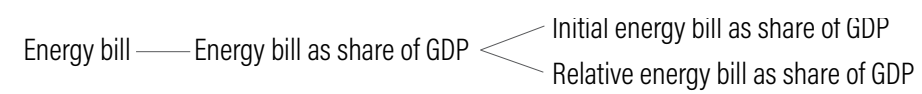

Relative energy bill as share of GDP $<$ Effect of energy bill on industry TFP — Total factor productivity industry

Note: GDP = gross domestic product; TFP = total factor productivity.

Source: Authors. 
Because externalities are modeled as a result of changes in biophysical drivers (e.g., land use, livestock, waste), a specific approach is used to model each of the externalities related to these drivers, including their valuation. For example, the social cost of carbon is used to value climate change impacts, while the cost of health (real health expenditure for the government) could be used to assess the monetary impact of energy-related air pollutants. In this way, externalities are only considered once and double counting is avoided. If two or more approaches are used to capture and value externalities, this is explicitly reported. The use of two approaches would also lead to generating two output tables, to show how the different valuation approaches would affect the results.

\subsection{Comparison with Other Models}

GEM-India, jointly developed by WRI India and KnowlEdge Srl, begins with a focus on economic activity, represented through GDP, employment, and the depiction of various sectors-energy, transport, agriculture, livestock, industry, services, water and sanitation, health, and education. The interlinkages serve to illustrate the impacts of economic and policy changes on the different sectors. GEM-India is a tool for appraising policy options with a view to supporting the shift to a lower carbon development pathway, practically linking low carbon to development. Although various other models explore low-carbon policies relevant to sectors such as energy, transport, buildings, and even health and land use, in the Indian context, each model offers something different in its representation of the sectors and the data integrated within the model. This section summarizes the differences and similarities between GEM-India and some comparable models.

\section{Sustainable Alternative Futures for India}

(SAFARI): The SAFARI model, like the GEM-India model, is a system dynamics model. It was created by the Center for Science, Technology and Policy with the objective of highlighting what a sustainable alternative future would look like for India. However, the model is based on the demands that various developmental goals involve in terms of food, housing, health care, education, power, water, and transport. This model posits that the demand in these sectors is the driving factor for future changes in the economy through which impacts and scenarios are envisioned (CSTEP 2020). The GEMIndia model, on the other hand, relies on exogenous policy priorities for its structure, allowing modelers to test the likely outcomes of planned or desired interventions using a "what if" approach. In GEM-India, the driving variables are defined by these policy priorities, and outcomes include variables such as GDP, employment, government spending, and so on.

Additionally, in the GEM, GDP is an endogenous variable-that is, GDP is calculated within the model. This can help in noting the impacts that policies might have on GDP. The SAFARI model, on the other hand, is linked externally to a computable general equilibrium model that calculates the GDP impact on various sectors for SAFARI. This means GDP is an exogenous quantity for the SAFARI model (CSTEP 2021). The endogenous nature of GDP in the GEM leads to a dynamic consistency within the model through the feedback loops that lead to the calculation of GDP.

\section{Energy-Environment-Economy (E3)-India}

Model: Developed by Cambridge Econometrics, the E3-India model is a dynamic macro-econometric model envisioned around the augmentation and development of the renewable energy sector in India. The main purpose of the model is to analyze the burden of the cost of renewable energy development and how that burden is distributed across states. The model uses economic variables such as GDP, employment, and imports and exports, as well as variables related to energy and emissions, including fuel use, process emissions, and other $\mathrm{CO}_{2}$ e emissions. The $\mathrm{E}_{3}$ is an econometric model and, like the GEM, it does not assume an equilibrium condition with full employment or perfect markets; it relies on historical trends to estimate future behavior. However, unlike the GEM, which has a broader scope of appraising policy options for low-carbon development, the $E_{3}$ is focused on the renewables sector (Cambridge Econometrics 2017). Moreover, the $\mathrm{E}_{3}$ functions in the form of a Keynesian disequilibrium model, where the state-wise allocation of the renewable energy development burden and renewable energy assets is key. The GEM has a neoclassical approach to energy-economy modeling; it is driven by the market mechanisms consistent with such an approach, where production is a driving force for the economy and the determinant for key variables in the model. The GEM uses a supplyside approach to estimate economic performance, but extends the neoclassical approach by adopting a more comprehensive formulation for total factor productivity, based on contributions from several sectors (e.g., education, health, energy and other infrastructure, emissions) that estimate their output indicators in physical, not monetary, units. 
India Energy Security Scenarios (IESS): The National Institution for Transforming India (NITI Aayog), an agency of the Government of India, developed IESS, an energy accounting model. The model incorporates energy parameters on the demand and supply sides along with a cost analysis to help make the combinations of energy demand and supply and their cost implications clearer. The model is an Excel-based tool. It incorporates variables from sectors such as transport, buildings, industry, and agriculture, but only in terms of their energy requirements or demand (NITI Aayog 2015; Dubash et al. 2015). The similarity between the models is that certain assumptions in the model can be modified and the scenarios then are automatically adjusted to incorporate assumptions. The GEMIndia model includes a more detailed representation of the economy than the IESS, including the health and education sectors, emission calculations, forests, land use, and so on, but it does include energy demand and power generation. Another key difference between the two models is that the GDP is endogenous in GEM and exogenous in the IESS. The latter has three predefined trajectories of GDP from which to choose, but that is not the case for the GEM (NITI Aayog 2015).

TIMES-MARKAL: The TIMES (the integrated MARKAL-EFOM system) and MARKAL (market allocation) models were developed by the Energy Technology Systems Analysis Programme (ETSAP) of the International Energy Agency. Based on linear programming, the TIMES-MARKAL model is a dynamic equilibrium model. The model attains this dynamic equilibrium by maximizing the total surplus of consumers and suppliers (ETSAP 2008). The GEM, on the other hand, is not an equilibrium model and does not optimize decisions. However, both models find their basis in neoclassical theory and focus on the environment, the energy sector, and the economy. The TIMES-MARKAL model takes the service demands exogenously to determine the final energy and other co-benefits; in the GEM, these demands are determined by other macroeconomic factors defined within the model in a self-propagating manner through feedback loops.

Energy Policy Simulator: India's Energy Policy Simulator (EPS) has been jointly developed by Energy Innovation LLC and WRI. It is also a system dynamics model that considers multiple sectors and aims to inform policymakers about climate and energy policies that will reduce GHG emissions. The key differences between the EPS and GEM-India are in the disaggregation of the data being used and the way each sector is being considered. For instance, EPS only considers health impacts caused by emissions from major air pollutants such as sulfur oxides, nitrogen oxides, and fine particulate matter, whereas GEM-India incorporates the health sector both in terms of impacts and infrastructure, as well as air pollutants (14 different air pollutants are calculated in GEM, from final energy use and power generation). The GEM-India model considers the transport sector as a part of the fuel sector, whereas the EPS has separated the two. In terms of data disaggregation, GEM-India relies on national sources to the extent possible and dives into greater detail in sectors such as forests, education, health, and employment compared with the EPS. The most significant difference, however, is that the EPS has been constructed in a way that allows it to represent multiple country contexts based on a generic systems diagram, whereas the GEM-India is a model constructed specifically for the Indian context, with customization applied to variables, equations, and data inputs (Energy Innovation LLC 2020). However, the EPS does provide the flexibility of populating the input data based on the country context, much like the GEM. Figures 15 and 16 give examples of the structural differences between the EPS and GEM's depiction of health-related variables.

\section{Figure 15 | Causal Tree from the EPS on Health Benefits}

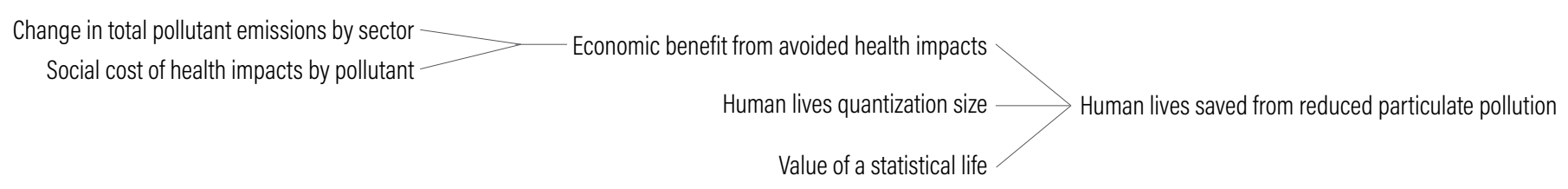

Source: https://us.energypolicy.solutions/docs/download.html. 

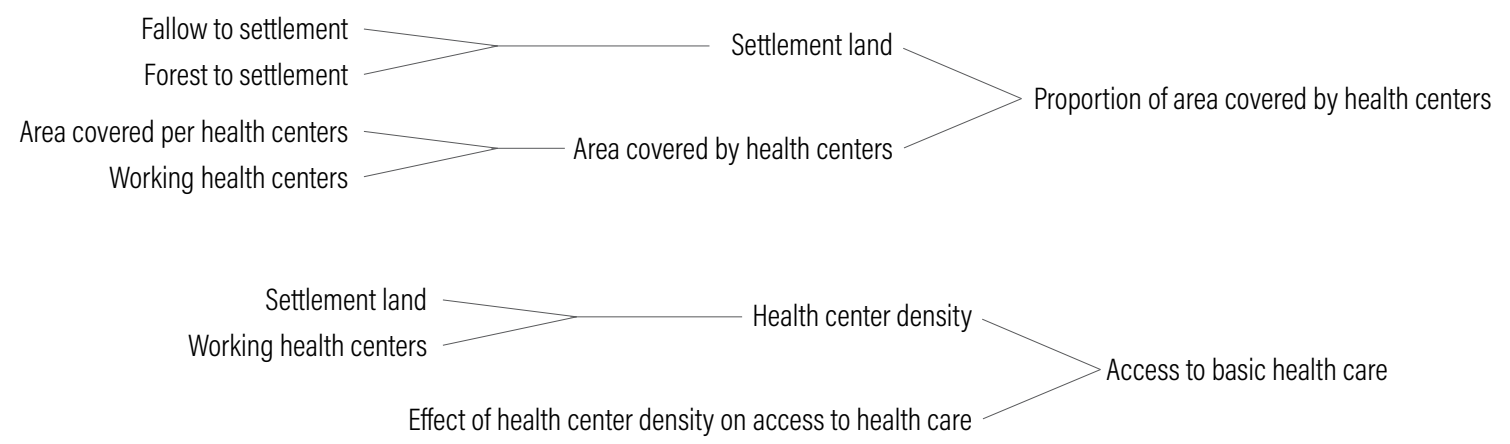

Source: Authors,

Each model offers a different perspective for future economic functioning and differs in focus and structure. However, there are similarities in how each sector is considered and differences in how they are represented. GEM-India is, therefore, another tool to assess how the future might look under a low-carbon development pathway.

\subsection{Assumptions and Limitations}

The assumptions that GEM-India has been built upon serve to ensure that the historical behavior of the model is calibrated against the data sources used, and to assess how changes in certain assumptions affect future forecasts. After the calibration period (2000-2020), ${ }^{11}$ all these assumptions remain unchanged unless affected by policies for the baseline or business-as-usual case.

Using system dynamics as a modeling methodology has the benefit that, in GEM-India, most assumptions are explicitly represented in the module sketches, which provides a high degree of transparency regarding the assumptions used. In some instances, input data for table functions (time series variables) are calculated using the statistical data collected to generate the parameters used in GEM. One such variable is the amount of agricultural land per capita, which is calculated based on total population and total agricultural land area; it is used to forecast the desired amount of agricultural land, and hence to predict land conversion resulting from this demand for agricultural land. This means that certain trends, such as a reduction in agricultural land, are kept exogenous and so are implicitly captured by these time series variables. In most instances, these time series functions use the latest available data points to generate forecasts; however, the data are critically reviewed with country context experts to decide whether a constant value, which would represent the discontinuation of a trend, is acceptable in each instance.
A few examples for explicitly represented assumptions are given below.

Government spending: The major assumptions fall in the category of investments, government spending, and production. The shares of the government budget that are spent on government consumption and government investment are calculated based on historical statistics on government consumption and investment. Government consumption and investment expenditures are divided by the total government budget to obtain the share of government spending that is consumption expenditure and the share of government budget that is invested.

The share of investments is then used to forecast the government portion of total nominal investment that flows into the agriculture, industry, and services modules. A similar approach is taken for the share of government revenues that is invested in health care or education (calculated by dividing historical spending on health care and historical spending on education by the government budget).

Macroeconomy: Assumptions here affect the extent to which growth is forecast in the industry and services sectors. The industry and services modules use a Cobb-Douglas production function to forecast economic growth in these sectors based on capital, labor, and total factor productivity (Equation 3).

$\square \quad$ In this instance, the share of investments flowing into the respective sectors, assumed to be equivalent to the sectors' contribution to total real GDP obtained from statistics, is assumed constant after the last data point, which may omit that more investments may flow into the services sector in the future. Modifications have to be made when setting up scenario assumptions (e.g., if the government is aiming 
at the implementation of an economic transformation plan that favors services, a new scenario could be created that assumes a higher portion of investments being destined for the services sector).

\section{Equation 3: Formulas for the calculation of real GDP industry and real GDP services}

real GDP industry

=initial GDP industry*(relative capital industry ${ }^{\text {capital }}$

elasticity industry)

*(relative employment level industry labor elasticity industry)

*total factor productivity industry

real GDP services

$=$ initial GDP services* ${ }^{*}$ (relative capital services ${ }^{\text {capital }}$ elasticity services

*(relative employment level services ${ }^{\text {labor elasticity services }}$ *total factor productivity services

Energy: The energy sector assumptions include values on energy efficiency, employment in power generation by technology and in terms of construction and operations of power plants as well as deriving the energy demand from GDP and historical data.

Historical energy efficiency improvements are assumed at 1 percent per year, based on historical trends of energy demand and energy intensity.

Employment per megawatt (MW) of power generation: In this instance, time series information on both construction employment per MW of capacity and operations and maintenance employment per MW of capacity were obtained from the literature (Greenpeace 2009). Technology-specific multipliers are used to ensure that changes in the composition of the power generation sector are reflected in total sectoral employment provided.

Energy demand is driven by relative GDP, relative population, and energy prices (which stimulate conservation and fuel switching). In this instance, historical time series data on energy demand by sector and fuel are used for validation purposes, not as inputs. Given that population and total real GDP are calibrated according to historical statistics, so that in both instances the behavior of these variables is generated endogenously, the elasticities of each sector are calibrated to ensure that energy demand is forecast aligned with statistical data.
Agriculture: the share of agriculture land under sustainable management practices.

Waste: the shares of waste that are collected, sent to landfills, recycled, used for energy recovery, and so on.

Emissions: GHG emission intensity of the industrial sector (IPPU emissions).

The time series data used for GHG emissions intensity of the industrial sector, specifically IPPU, are calculated based on historical IPPU emissions and industry real GDP. The GHG emissions from IPPU for each available data point are divided by industrial real GDP.

Emissions from energy use: Emissions from energy use are calculated using IPCC (2006) emission factors for sectoral energy use by fuel (i.e., coal, natural gas, petroleum products, and biomass). Emission factors are based on IPCC estimates and aligned to ensure that energy emissions are reproduced according to historical statistics.

Emissions from power generation are a function of the share of each fossil fuel in power generation (i.e., oil, gas, and coal) and a respective emission factor. If the share of fossil fuel-based sources is zero, there are no emissions from generated electricity.

Emissions from wastewater: Emissions from residential and commercial wastewater are calculated based on the wastewater emission intensity per capita (calculated by dividing emissions from residential and commercial wastewater by total population). Industrial wastewater emission intensity is forecast based on industrial real GDP and the GHG emission intensity of industrial wastewater (calculated by dividing emissions from industrial wastewater by industrial real GDP).

Climate: GEM-India includes three specific climate scenarios for the simulations. A switch can be used to determine the scenario that will be simulated. These RCPs have been used for two aspects-the impact on precipitation and the impact on temperature. The impact on precipitation has been linked to floods and water scarcity, which affect the agricultural sector as well as water availability. The temperature rise has not been linked to other variables in the model at the current stage of development. In other country applications of the GEM, temperature has been linked to power generation efficiency, power distribution losses and energy demand in buildings. 


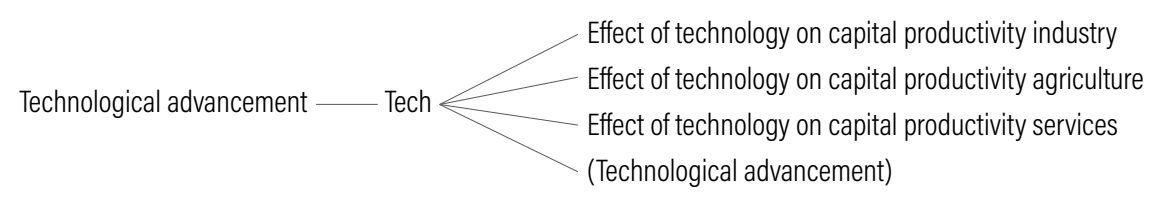

Source: Authors.

These sectors have been assimilated within GEM-India using time series data from the years 2000-2020. To the extent possible, the model is built upon official government data sources-documents, reports, and data sets (Appendix B). If such data were unavailable, the model relied on country-specific data published by international institutions. The model has incorporated more than 270 variables mapping major economic and industrial drivers, indicators of environmental emission, and impacts. The model also looks at sectors such as health and education to begin incorporating the impacts of policy changes on the social sector. This requires substantial data to be available across sectors that drive consumption and those that are sensitive to policy changes.

These sectors, within GEM-India, have been represented at an aggregate level and therefore do not represent outputs and policy changes at a subsector scale. GEM-India is capable of representing impacts at the national and sectoral levels but not at the subnational or subsectoral scale. This means that the policy changes enacted within a particular sector have to be applied to the entire sector rather than to their more relevant constituents. For instance, technological advancement as a policy switch affects capital productivity in the entire industry, services, and agriculture sectors, although it may be more relevant for the manufacturing sector within industry. Figure 17 represents the impacts of technological advancement on these sectors. There is a feedback loop where technological advancement leads to capital productivity and further technological advancement. This reinforces the fact that these models are a simplistic representation of the real world, but in order to achieve desired results, such simplifications might be necessary, although they give rise to certain limitations.

Apart from the simplifications within the structure of the model, a significant limitation in the data collection was the lack of continuous data from 2000 to 2020 across sectors. The fragmentation in data has resulted in the application of certain reasonable assumptions (as stated above) in the mathematical model underlying GEM-India. The demographic data are fragmented because of the frequency of surveys such as the census or the National Sample Survey Office. The decadal census influences the health, sanitation, and education sectors as well, in terms of access, infrastructure, spending, and the demographic disaggregation of the relevant data. These data gaps have been either addressed through supplementary data sets, explicitly listed as gaps, or resulted in the variable being discarded from analysis.

There exist certain disparities between data from national and international sources, independent studies, and so on. These disparities affect the accuracy of the model and result in uncertainties in the model's results. The GEM-India model has been customized to represent the Indian context in a simplified manner; as such, it uses assumptions to simplify reality and has also used relevant proxies or discarded certain variables that would have otherwise increased uncertainties in the model results. Further limitations related to specific sectors have been incorporated in Appendix B.

\section{DISCUSSIONS AND WAY FORWARD}

The GEM is a causal-descriptive model that was constructed using CLDs as its key building blocks. These CLDs qualitatively represent different sectors that interact within the economy and their interrelationships. These relationships are based on input data and model calculations that are calibrated and can be tested for accuracy as well. GEM-India is notable for its customization to the country's context and to the conditions under which it operates. The flexible nature of the model allows for space to develop it further and include aspects that provide a deeper understanding of policy impacts.

The outputs of such models are "what if" scenarios that convey a set of conditions and assumptions and portray the impact of a particular mix of policy options from various sectors. The other advantage of GEM- 
India is that it is a multisector model and so presents a broader view of the economy than sector-specific or issue-specific models. The wide sectoral coverage and its flexibility make it possible to use GEM-India as a tool for evaluating the different impacts of policy options across social, economic, and environmental indicators, and across several sectors.

A disadvantage of GEM-India is that it lacks detail at the sectoral level. Other sectoral models exist (e.g., for the economy, or for energy demand and supply) that include more detail (e.g., more economic sectors or more technologies). Nevertheless, GEM-India is already complex in its horizontal integration, and adding more vertical detail may make it too cumbersome to use and maintain effectively. The GEM-India model will be developed further and dive deeper into the issues of distributive impacts and the cost-benefit components of the policy options and scenarios being studied. The major challenge in studying distributive impacts through models, in the Indian context, is the unavailability of disaggregated data at the national level. However, a high level of disaggregation is present in the data gathered from national sources. The data on employment and education, for instance, have been collected across gender and age cohorts, which can help researchers proceed in a direction that might make it possible to study the distributive impacts of policy changes across these cohorts.

Further, the platform of the GEM as a system dynamics model can also help customize the model for a subnational scale using spatially disaggregated data. This would require the development of entirely new modules, given the context that the model is being modified for. However, such customization may lead to some insights at a regional and/or state level as well. 


\section{APPENDIX A: ECONOMIC AND SECTORAL INDICATORS}

Table A1 | Sector-wise Data Sets and Sources Used

SECTOR/GROUP

OF INDICATORS

\section{VARIABLES}

Total real GDP

Real GDP growth rate

I. Real GDP

Real GDP agriculture

Real GDP industry

Real GDP services

Total annual $\mathrm{CO}_{2}$ e emissions

Total $\mathrm{CO}_{2}$ e emission from energy

Total $\mathrm{CO}_{2}$ e emission from industry

II. Emission

Total $\mathrm{CO}_{2}$ e emissions from livestock

Total $\mathrm{CO}_{2}$ e emissions from managed soils

Total $\mathrm{CO}_{2}$ e emissions from waste

Total employment

Employment agriculture

Employment industry

III. Employment

Employment service

Employment for power generation

Green jobs

Total normalized energy demand

Total country normalized biofuels and waste demand (by sector)

Total country normalized natural gas demand (by sector)

IV. Energy Demand

Total country normalized coal demand (by sector)

Total country normalized electricity demand (by sector)

Total country normalized petroleum demand (by sector)

Agriculture land

Forest

V. Land-Use

Settlement land

Fallow land 


\section{APPENDIX B: DATA SOURCES AND GAPS}

Table B1 | Sector-wise Data Sets and Sources Used

\begin{tabular}{|c|c|c|c|c|}
\hline \multirow{2}{*}{ SECTOR } & \multirow{2}{*}{ VARIABLE NAME } & DATA AVAILABLE & $\begin{array}{l}\text { DATA FROM } \\
\text { NATIONAL } \\
\text { SOURCES }\end{array}$ & \multirow{2}{*}{ DATA SOURCES } \\
\hline & & $\begin{array}{l}\text { (YES/NO/ } \\
\text { PARTIALLY) }\end{array}$ & $\begin{array}{l}\text { (YES/NO/ } \\
\text { PARTIALLY) }\end{array}$ & \\
\hline \multirow{8}{*}{ Macroeconomy } & $\begin{array}{l}\text { System of National } \\
\text { Accounts }\end{array}$ & Yes & Yes & $\begin{array}{l}\text { Data.govin } \\
\text { - Agriculture Statistics, } 2019 \\
\text { - Economic Survey, 2019-2020 } \\
\text { - Ministry of Statistics and Programme } \\
\text { Implementation } \\
\text { - } \text { IMF }\end{array}$ \\
\hline & Investments & Yes & No & The World Bank \\
\hline & Private Final Consumption & Yes & Yes & $\begin{array}{l}\text { Ministry of Statistics and Programme } \\
\text { Implementation }\end{array}$ \\
\hline & Government Spending & Yes & Partially & $\begin{array}{l}\text { Ministry of Statistics and Programme } \\
\text { Implementation } \\
\text { World Development Indicators }\end{array}$ \\
\hline & Net Value Added & Partially & Yes & Data.govin \\
\hline & Gross Value Added & Yes & Yes & Directorate of Economic and Statistics \\
\hline & Taxes and Revenue & Yes & Yes & The World Bank \\
\hline & Trade & Yes & No & International Monetary Fund \\
\hline \multirow{3}{*}{ Agriculture } & $\begin{array}{l}\text { Agriculture and Livestock } \\
\text { Value Added }\end{array}$ & Yes & Yes & $\begin{array}{l}\text { Ministry of Statistics and Programme } \\
\text { Implementation }\end{array}$ \\
\hline & $\begin{array}{l}\text { Agriculture and Livestock } \\
\text { Production }\end{array}$ & Yes & Yes & Data.govin \\
\hline & $\begin{array}{l}\text { Area under Principal } \\
\text { Crops }\end{array}$ & Yes & Yes & $\begin{array}{l}\text { Data.govin } \\
\text { Database on Indian Economy: Reserve Bank } \\
\text { of India }\end{array}$ \\
\hline \multirow{6}{*}{ Education } & $\begin{array}{l}\text { Gross Enrollment Ratio } \\
\text { (at various levels of } \\
\text { education) }\end{array}$ & Yes & Partially & $\begin{array}{l}\text { - Ministry of Education } \\
\text { - The World Bank }\end{array}$ \\
\hline & $\begin{array}{l}\text { Literacy Rate }(15+\text { years; } \\
\text { disaggregated by age and } \\
\text { gender) }\end{array}$ & Yes & No & The World Bank \\
\hline & $\begin{array}{l}\text { Illiterate Population ( } 15+ \\
\text { years; disaggregated by } \\
\text { age and gender) }\end{array}$ & Yes & No & The World Bank \\
\hline & $\begin{array}{l}\text { Gross Intake Ration (at } \\
\text { various levels) }\end{array}$ & Yes & Partially & Ministry of Education \\
\hline & $\begin{array}{l}\text { Graduation/Survival Rate } \\
\text { (at various levels) }\end{array}$ & Yes & Partially & Ministry of Education \\
\hline & $\begin{array}{l}\text { Number of Educational } \\
\text { Institutions }\end{array}$ & Yes & Partially & Ministry of Education \\
\hline
\end{tabular}


Table B1 | Sector-wise Data Sets and Sources Used (Cont.)

\begin{tabular}{|c|c|c|c|c|}
\hline \multirow[t]{2}{*}{ SECTOR } & \multirow[t]{2}{*}{ VARIABLE NAME } & DATA AVAILABLE & $\begin{array}{l}\text { DATA FROM } \\
\text { NATIONAL } \\
\text { SOURCES }\end{array}$ & \multirow{2}{*}{ DATA SOURCES } \\
\hline & & $\begin{array}{l}\text { (YES/NO/ } \\
\text { PARTIALLY) }\end{array}$ & $\begin{array}{l}\text { (YES/NO/ } \\
\text { PARTIALLY) }\end{array}$ & \\
\hline \multirow{3}{*}{ Education } & Gender Parity Index & Yes & Partially & Ministry of Education \\
\hline & & & & \\
\hline & Dropout Rates & Yes & Partially & Ministry of Education \\
\hline \multirow{6}{*}{$\begin{array}{l}\text { Forest and } \\
\text { Land Use }\end{array}$} & Natural Capital & Yes & Partially & Forest Survey of India \\
\hline & $\begin{array}{l}\text { All India Estimates of Tree } \\
\text { and Mangrove Cover }\end{array}$ & Yes & Partially & Data.gov.in \\
\hline & Economic Contribution & Yes & Yes & $\begin{array}{l}\text { Ministry of Statistics and Programme } \\
\text { Implementation }\end{array}$ \\
\hline & Import Value & No & No & Food and Agriculture Organization \\
\hline & Export Value & No & Yes & Food and Agriculture Organization \\
\hline & Production & No & Yes & Food and Agriculture Organization \\
\hline \multirow{9}{*}{ Infrastructure } & Road Density & Yes & Yes & $\begin{array}{l}\text { Basic Road Statistics of India } \\
\text { annual Reports of Ministry of Road, Trans- } \\
\text { port and Highways }\end{array}$ \\
\hline & Road Construction & No & No & \\
\hline & $\begin{array}{l}\text { Road-Capital Expenditure, } \\
\text { O\&M cost }\end{array}$ & Yes & Partially & $\begin{array}{l}\text { Road Statistics of India } \\
\text { Annual Reports of Ministry of Road, Trans- } \\
\text { port and Highways }\end{array}$ \\
\hline & $\begin{array}{l}\text { Road Infrastructure } \\
\text { Employment }\end{array}$ & Yes & Partially & $\begin{array}{l}\text { - Annual Reports of Ministry of Road, } \\
\text { - Transport and Highways }\end{array}$ \\
\hline & $\begin{array}{l}\text { Total Number of } \\
\text { Registered Vehicles }\end{array}$ & Yes & Yes & $\begin{array}{l}\text { Basic Road Statistics of India series } \\
\text { Annual Reports of Ministry of Road, Trans- } \\
\text { port and Highways }\end{array}$ \\
\hline & $\begin{array}{l}\text { Kilometers Traveled } \\
\text { Disaggregated by Vehicle } \\
\text { Type }\end{array}$ & No & No & \\
\hline & $\begin{array}{l}\text { Air Pollution from } \\
\text { Transport by Pollutant }\end{array}$ & No & No & \\
\hline & Rail Network & Yes & Yes & $\begin{array}{l}\text { - Indian Rail Yearbook } \\
\text { - Indian Rail Statistics }\end{array}$ \\
\hline & Rail Energy Consumption & Yes & Yes & $\begin{array}{l}\text { - Indian Rail Yearbook } \\
\text { - Indian Rail Statistics }\end{array}$ \\
\hline
\end{tabular}


Table B1 | Sector-wise Data Sets and Sources Used (Cont.)

\begin{tabular}{|c|c|c|c|c|}
\hline \multirow[t]{2}{*}{ SECTOR } & \multirow[t]{2}{*}{ VARIABLE NAME } & DATA AVAILABLE & $\begin{array}{l}\text { DATA FROM } \\
\text { NATIONAL } \\
\text { SOURCES }\end{array}$ & \multirow[t]{2}{*}{ DATA SOURCES } \\
\hline & & $\begin{array}{l}\text { (YES/NO/ } \\
\text { PARTIALLY) }\end{array}$ & $\begin{array}{l}\text { (YES/NO/ } \\
\text { PARTIALLY) }\end{array}$ & \\
\hline \multirow{12}{*}{$\begin{array}{l}\text { Waste } \\
\text { Management }\end{array}$} & $\begin{array}{l}\text { Waste Generation per } \\
\text { Capita }\end{array}$ & No & No & \\
\hline & Total Waste Generation & No & Yes & $\begin{array}{l}\text { Solid Waste Management-Annual Report, } \\
\text { Central Pollution Control Board }\end{array}$ \\
\hline & Total Waste Collection & Yes & Partially & $\begin{array}{l}\text { Solid Waste Management-Annual Report, } \\
\text { Central Pollution Control Board }\end{array}$ \\
\hline & Waste Incineration & No & No & \\
\hline & Waste Landfilled & Yes & Partially & $\begin{array}{l}\text { Solid Waste Management-Annual Report, } \\
\text { Central Pollution Control Board }\end{array}$ \\
\hline & Waste Recycled & No & No & \\
\hline & $\begin{array}{l}\text { Waste Recycling Unit } \\
\text { (registered and un- } \\
\text { registered) }\end{array}$ & Yes & Partially & $\begin{array}{l}\text { Plastic Waste Management-Annual Report, } \\
\text { Central Pollution Control Board }\end{array}$ \\
\hline & Waste Composition & No & No & \\
\hline & Employment & No & No & \\
\hline & Emissions & No & No & \\
\hline & Land Requirement & No & No & \\
\hline & $\begin{array}{l}\text { Government Efforts } \\
\text { (taxation, investment) }\end{array}$ & No & No & \\
\hline \multirow{10}{*}{ Health } & $\begin{array}{l}\text { Number of Healthcare } \\
\text { Professionals (doctors } \\
\text { and nurses) }\end{array}$ & Yes & Partially & Indian Statistical Yearbook \\
\hline & $\begin{array}{l}\text { Health Infrastructure } \\
\text { (hospitals and primary } \\
\text { health centers) }\end{array}$ & Yes & Yes & Indian Statistical Yearbooks \\
\hline & $\begin{array}{l}\text { Share of Agriculture } \\
\text { Irrigated }\end{array}$ & Yes & Yes & $\begin{array}{l}\text { Land Use Statistics 2000-17, Directorate of } \\
\text { Economics and Statistics }\end{array}$ \\
\hline & $\begin{array}{l}\text { Share of Irrigated Land } \\
\text { Using Surface Water }\end{array}$ & Yes & Yes & $\begin{array}{l}\text { Land Use Statistics 2000-17, Ministry of } \\
\text { Economic s and Statistics }\end{array}$ \\
\hline & $\begin{array}{l}\text { Share of Irrigated Land } \\
\text { Using Ground Water }\end{array}$ & Yes & Yes & $\begin{array}{l}\text { Land Use Statistics 2000-17, Ministry of } \\
\text { Economics and Statistics }\end{array}$ \\
\hline & Residential Water Supply & No & No & \\
\hline & Industrial Water Supply & No & No & \\
\hline & $\begin{array}{l}\text { Agriculture Water } \\
\text { Demand }\end{array}$ & Yes & Partially & $\begin{array}{l}\text { Water and Related Statistics, Central Water } \\
\text { Commission }\end{array}$ \\
\hline & $\begin{array}{l}\text { Residential Water } \\
\text { Demand }\end{array}$ & No & No & \\
\hline & Industrial Water Demand & No & No & \\
\hline
\end{tabular}




\begin{tabular}{|c|c|c|c|c|}
\hline \multirow[t]{2}{*}{ SECTOR } & \multirow[t]{2}{*}{ VARIABLE NAME } & DATA AVAILABLE & $\begin{array}{l}\text { DATA FROM } \\
\text { NATIONAL } \\
\text { SOURCES }\end{array}$ & \multirow[t]{2}{*}{ DATA SOURCES } \\
\hline & & $\begin{array}{l}\text { (YES/NO/ } \\
\text { PARTIALLY) }\end{array}$ & $\begin{array}{l}\text { (YES/NO/ } \\
\text { PARTIALLY) }\end{array}$ & \\
\hline GHG Emissions & $\begin{array}{l}\text { Total Annual GHG } \\
\text { Emissions }\end{array}$ & Yes & Partially & India Biennial Update Report \\
\hline \multirow{9}{*}{ Industry } & Labor Force & Yes & Yes & Labour Statistics \\
\hline & Total Employment & Yes & Yes & $\begin{array}{l}\text { Labour Statistics; India Statistical Yearbook; } \\
\text { Labour Bureau, Ministry of Labour and } \\
\text { Employment }\end{array}$ \\
\hline & Employment in Agriculture & Yes & Partially & $\begin{array}{l}\text { Labour Statistics; India Statistical Yearbook; } \\
\text { Labour Bureau, Ministry of Labour and } \\
\text { Employment }\end{array}$ \\
\hline & Employment in Industry & Yes & Yes & $\begin{array}{l}\text { Labour Statistics; India Statistical Yearbook; } \\
\text { Labour Bureau, Ministry of Labour and } \\
\text { Employment }\end{array}$ \\
\hline & Employment in Services & Yes & Partially & $\begin{array}{l}\text { Labour Statistics; India Statistical Yearbook; } \\
\text { Labour Bureau, Ministry of Labour and } \\
\text { Employment }\end{array}$ \\
\hline & Average Earnings & Yes & Yes & $\begin{array}{l}\text { Labour Statistics; India Statistical Yearbook; } \\
\text { Labour Bureau, Ministry of Labour and } \\
\text { Employment }\end{array}$ \\
\hline & Industrial Waste & No & & \\
\hline & $\begin{array}{l}\text { Industrial Waste Water } \\
\text { Generation }\end{array}$ & Yes & Partially & Jal Shakti Ministry \\
\hline & $\begin{array}{l}\text { Grossly Polluting } \\
\text { Industries }\end{array}$ & Yes & Partially & Jal Shakti Ministry \\
\hline \multirow{6}{*}{ Energy } & $\begin{array}{l}\text { Supply of Electricity } \\
\text { (by source, thermal } \\
\text { generation and } \\
\text { renewable- } \\
\text { disaggregated, e.g., wind, } \\
\text { solar) }\end{array}$ & Yes & Partially & $\begin{array}{l}\text { Energy Statistics, Ministry of Statistics and } \\
\text { Programme Information }\end{array}$ \\
\hline & $\begin{array}{l}\text { Total Primary Energy } \\
\text { Supply by Source }\end{array}$ & Yes & Partially & $\begin{array}{l}\text { Energy Statistics, Ministry of Statistics and } \\
\text { Programme Information }\end{array}$ \\
\hline & $\begin{array}{l}\text { Production Capacity of } \\
\text { Electricity by Source } \\
\text { (thermal generation } \\
\text { and renewables } \\
\text { disaggregated, e.g., wind, } \\
\text { solar }\end{array}$ & Yes & Partially & $\begin{array}{l}\text { Energy Statistics, Ministry of Statistics and } \\
\text { Programme Information }\end{array}$ \\
\hline & Energy Investment & Yes & Partially & Annual Report, Central Electricity Authority \\
\hline & Plant Load Factor & Yes & Partially & Annual Reports, Ministry of Power \\
\hline & $\begin{array}{l}\text { Total Energy Demand (by } \\
\text { source) }\end{array}$ & Yes & Partially & National Electricity Plan \\
\hline
\end{tabular}




\begin{tabular}{|c|c|c|c|c|}
\hline \multirow[t]{2}{*}{ SECTOR } & \multirow[t]{2}{*}{ VARIABLE NAME } & DATA AVAILABLE & $\begin{array}{l}\text { DATA FROM } \\
\text { NATIONAL } \\
\text { SOURCES }\end{array}$ & \multirow[t]{2}{*}{ DATA SOURCES } \\
\hline & & $\begin{array}{l}\text { (YES/NO/ } \\
\text { PARTIALLY) }\end{array}$ & $\begin{array}{l}\text { (YES/NO/ } \\
\text { PARTIALLY) }\end{array}$ & \\
\hline \multirow{8}{*}{ Energy } & $\begin{array}{l}\text { Demand of Petroleum } \\
\text { Products }\end{array}$ & No & No & IEA Energy Demand Data \\
\hline & $\begin{array}{l}\text { Total Energy Demand } \\
\text { (sectors: residential, } \\
\text { commercial, industrial, } \\
\text { transport) }\end{array}$ & Yes & No & $\begin{array}{l}\text { Energy Statistics, Ministry of Statistics and } \\
\text { Programme Information }\end{array}$ \\
\hline & $\begin{array}{l}\text { Electricity Final } \\
\text { Consumption by Sector }\end{array}$ & Yes & Partially & $\begin{array}{l}\text { Energy Statistics, Ministry of Statistics and } \\
\text { Programme Information }\end{array}$ \\
\hline & $\begin{array}{l}\text { Energy Prices and Costs } \\
\text { (disaggregated by } \\
\text { consumer sector) }\end{array}$ & Yes & Partially & $\begin{array}{l}\text { Energy Statistics, Ministry of Statistics and } \\
\text { Programme Information }\end{array}$ \\
\hline & Fossil Fuel Emissions & Yes & Partially & $\begin{array}{l}\text { Central Electricity Authority } \\
\text { India Biennial Update Report GHG Platform } \\
\text { India }\end{array}$ \\
\hline & Primary Energy Supply & Yes & Partially & $\begin{array}{l}\text { Energy Statistics, Ministry of Statistics and } \\
\text { Programme Information }\end{array}$ \\
\hline & Employment & Yes & Partially & Annual Reports, Ministry of Power \\
\hline & $\begin{array}{l}\text { Final Consumption Data } \\
\text { in KTOE }\end{array}$ & Yes & Partially & $\begin{array}{l}\text { Energy Statistics, Ministry of Statistics and } \\
\text { Programme Information }\end{array}$ \\
\hline
\end{tabular}

Note: MoSPI = Ministry of Statistics and Programme Implementation; 0\&M = operations and maintenance; IMF = International Monetary Fund; IEA = International Energy Agency; GHG = greenhouse gas; $\mathrm{KTOE}=$ kilotonnes of equivalent.

Below are the main approaches used for sourcing and adapting the input data set to GEM-India:

1. Forests: The data on forest cover in India are published biennially by the Forest Survey of India. The GEM-India uses the data from 2000 to 2019 and there have been several changes in terms of how forests are defined (Forest Survey of India 2019). The Forest Survey's current definition states that any parcel of land that has a canopy density of more than 10 percent can be classified as a forest. The limitations of the same are that agricultural land, parks, and plantations could also be classified as forests under the new definition. This might lead to an overestimation of forest resources in the country. The economic aspect of forests includes the production of timber and non-timber forest produce and is classified under forestry in the economic census and data on macroeconomic indicators. The definition here has largely remained consistent but there have been reports where forestry has been combined with other agriculture-allied economic activities. However, a disaggregation is generally available.

2. Macroeconomic indicators: The GEM-India uses macroeconomic data on income, GDP, total value added, taxes, and government spending. The data have been collected primarily from the Ministry of Statistics and Programme Implementation and are intended to help calibrate and validate the model and the results it generates. Although the macroeconomic variables have remained consistent through 2000-2019, there have been some changes in how they are represented-whether in a disaggregated manner or combined into one variable in an aggregated manner. In some instances where aggregation was present in some cases and disaggregation in others, the authors added the relevant variables to represent production to represent the same production values throughout the time frame.

3. Education: The data for education mainly include enrollment rates, literacy rates, and survival rates by level of education, gender, and some details on vocational trainings. Overall, the data on education are sufficiently detailed to help build variables into the model.

4. Agriculture and livestock: The agriculture data are a collection of variables from the land use data that reflect the total area under agriculture, the type of agricultural land, and its irrigation status. The economic aspects of the agricultural sector are covered through the MoSPI data and includes data on major crops (the area they cover as well as their production value). The data on allied sectors such as forestry, fisheries, and so on are also available and give the details of production 
from the sector. The livestock data, on the other hand, are sparse and fragmented, with some years' data containing the details of the types of ruminants. The economic data on livestock are also available from MoSPI's economic census data and have been included in the model.

5. Energy: The GEM uses data on energy demand, generation capacity, supply, and consumption, disaggregated by fuel source (coal, gas, and renewable sources such as wind or solar) and by sectors (transport, industry, agriculture, residential, and commercial). All energy-related data have been sourced from the annual energy statistics reports published by the Ministry of Statistics, India; the emissions from the power sector are taken from the National Electricity Plan. There are significant data gaps for the years 2000-2007 for most indicators, as well as a change in methodology and unit measure for certain indicators around 2010. Additional data on related emissions are sourced from the GHG platform India and India UNFCCC close, and the data on prices, cost, investment, and employment in the sector were sourced from the EPS model.

6. Transport: This includes variables on road and rail infrastructure. The road infrastructure data are collected from the Ministry of Road, Transport and Highways' annual statistical publications and infrastructure statistics, and the railway infrastructure data are collected from the Ministry of Railways' annual statistical publications (annual reports and yearbooks). The data collected reflect on the size of the network, utilization, network density, performance, vehicle fleet (road) and locomotive fleet (rail) investment and cost, and employment for roadways and railwaysspecifically, fuel consumption data for railways.
7. Waste management: The data for MSW (including plastic waste management) is sparse and only available for recent years (2015-2019). The data on MSW (including plastic waste) have been sourced from the Central Pollution Control Board's Annual report on waste management, 2019 (CPCB 2019).

8. Water supply \& water demand: Given the scarce information on water use by different sectors, it is possible to estimate required investments and estimated changes in water use, assuming the 55 -liter per capita threshold. Because total water use is not reliably calibrated in the model, estimating impacts on total country water stress would not be possible.

9. GHG emissions: The India UNFCCC inventories for 2000, 2007, 2010, 2014, and 2021 are currently in use. 


\section{ENDNOTES}

1. Nationally determined contributions are nonbinding national plans that highlight nations' climate action and domestic mitigation and adaptation measures (UNFCCC 2021).

2. System dynamics modeling is a methodology to create descriptive models that focus on the identification of causal relations influencing the creation and evolution of the issues being investigated. Its main pillars are feedback loops, delays, and nonlinearity through the explicit representation of stocks and flows

3. Please refer to the website for further information on the software: http://vensim.com.

4. Total factor productivity refers to the productivity value of factors of production (labor and capital) and pertains to the services and industry sector.

5. This emission factor comes from the India-specific section of an International Monetary Fund database.

6. The $\mathrm{CO}_{2}$ e emissions from industry depend on emissions per unit GDP and emission reduction from improved processes, both of which change with time.

7. Shadow variables, in Vensim, are variables that have been used multiple times in different modules or views and are represented in gray to avoid confusion. This multiplicity allows system dynamic models to allow a wide variety of linkages, which may not be possible in other kinds of models.

8. The use of "Time" here indicates that certain external factors and data have been used here to calculate the enrollment and survival rates.

9. "Stock" is any variable that does not reset and keeps accumulating or dwindling based on the "flow/rate" in and out of the stock, and "constants" are variables with fixed values in the model.

10. Price externalities incur equal costs and benefits within a system and hence do not have to be considered separately.

11. Calibration involves using historical data of a few years to generate results for later years and then comparing them with actual data for the later years. For instance, data from 2000-2010 will be fed into the model and the model-generated results will be compared with the data from 2011-2019/2020. 


\section{REFERENCES}

Bassi, Andrea M. 2015. "Moving Towards Integrated Policy Formulation and Evaluation: The Green Economy Model." Environment and Climate Technologies 5-19.

Cambridge Econometrics. 2017. E3 India. https://www.camecon.com/how/ e3-india-model/.

Centre for Monitoring Indian Economy. 2020. Economic Outlook India. Accessed June 2021. https://www.cmie.com/kommon/bin/sr.php?kall=wa rticle\&dt=2020-08-18\%2011:02:19\&msec=596

Climate Analytics and New Climate Institute. 2021. Climate Action Tracker. Accessed September 9, 2021. https://climateactiontracker.org/countries/ india/.

ClimateWatch. 2020. Historical GHG Emissions. https://www. climatewatchdata.org/ghg-emissions?regions=IND.

Covid-19 India. 2021. October 31. Accessed December 1, 2021. https://www. covid19india.org/.

CPCB (Central Pollution Control Board). 2019. Annual Report for the Year 2018-19 on Implementation of Solid Waste Management Rules. Delhi: CPCB. https://cpcb.nic.in/uploads/MSW/MSW_AnnualReport_2018-19.pdf.

CSTEP (Center for Study of Science, Technology and Policy). 2020. Energy and Emissions Implications for a Desired Quality of Life in India, via SAFARI. CSTEP.

CSTEP. 2021. Energy and Emissions Implications for a Desired Quality of Life in India, via SAFARI, CSTEP-RR-2021-04. CSTEP and DESTA.

Dubash, Navroz K., Radhika Khosla, Narsimha D. Rao, and K. Rahul Sharma. 2015. "CPR India." April. https://cprindia.org/sites/default/files/ Informing\%20India\%275\%20Energy\%20and\%20Climate\%20Debate_CPRIIASA.pdf.

Energy Innovation LLC. 2020، "Energy Policy Solutions." India Energy Policy Solutions, https://us.energypolicy.solutions/docs/index.html.

ETSAP (Energy Technology Systems Analysis Program), 2008. "Technology Collaboration Program-IEA." IEA-ETSAP.org. Accessed September 8, 2021 https://iea-etsap.org/index.php/etsaptool/model-generators/markal.

Forest Survey of India. 2019. State of Forest Report, Accessed July 2021 https://fsi.nic.in/forest-report-2019.

Goldin, Kenneth D. 1975. "Price Externalities Influence Public Policy." Public Choice 23: 1-10.

Government of India. 2018. https://cckpindia.nic.in/assets/INDIA_INDC_ TO_UNFCCC.pdf.

Greenpeace. 2009. Energy Sector Jobs to 2030: A Global Analysis. Greenpeace International.

International Labour Organization. 2020. Global Wage Report 2020-21: Wages and Minimum Wages in the Time of Covid-19. International Labour Organization. Accessed June 2021. https://wwwilo.org/global/ publications/books/WCMS_762534/lang--en/index.htm.
IPCC (Intergovernmental Panel on Climate Change). (2006). 2006 IPCC Guidelines for National Greenhouse Gas Inventories. (E. H. Prepared by the National Greenhouse Gas Inventories Programme, Ed.) Japan: Institute for Global Environmental Strategies.

IPCC. 2018. Summary for Policymakers. Special Report, IPCC.

IPCC. 2021. "AR6 Climate Change 2021: The Physical Science Basis." IPCC Sixth Assessment Report. Accessed September 9, 2021. https://www.ipcc. ch/report/ar6/wg1/downloads/report/IPCC_AR6_WGI_Full_Report.pdf.

Kim, Daniel H. 1994. "Reinforcing and Balancing Loops: Building Blocks of Dynamic Systems." In System Thinking Too/s, by Daniel H. Kim, 14-15. Pegasus Communications Inc.

NITI Aayog. 2015. "India Energy Security Scenarios 2047: Version 2.0 Handbook." India Energy Security Scenarios 2047: Version 2.0 Handbook. Energy Division, NITI Aayog, Government of India, August.

Nordhaus, W. D. 2017. "Revisiting the Social Cost of Carbon." PNAS 11 (7): $1518-23$.

NRDC (Natural Resources Defense Council). 2017. The Road From Paris: India's Progress toward Its Climate Pledge. Washington, DC: Natural Resources Defense Council.

NRDC. 2020. "NRDC." September. Accessed September 2021. https://www. nrdc.org/sites/default/files/india-progress-climate-pledge-2019-ib.pdf.

OECD (Organisation for Economic Co-operation and Development). 2021. India: Real GDP Forecast, https://data.oecd.org/gdp/real-gdp-forecast.ht.

Pai, Sandeep, Hashim Zerriffi, Jessica Jewell, and Jalvik Pathak. 2020. "Solar Has Greater Techno-Economic Resource Suitability than Wind for Replacing Coal Mining Jobs." https://iopscience.iop.org/ article/10.1088/1748-9326/ab6c6d.

Ricke, K., L. Drouet, K. Caldeira, and M. Tavoni. 2019. "Country-Level Social Cost of Carbon." Nature Climate Change 895-900. doi:https://doi. org/10.1038/s41558-018-0282-y.

SEI (Stockholm Environment Institute). 2021. "Introducing IBC: The Integrated Benefits Calculator." Stockholm Environment Institute, https:// leap.sei.org/default.asp?action=|BC.

United Nations. 2021. World Economic Situation and Prospects 2021. https://www.un.org/development/desa/dpad/publication/worldeconomic-situation-and-prospects-2021/.

UNEP (United Nations Environment Programme)، 2020. Emissions Gap Report 2020. Nairobi: UNEP.

UNFCCC (United Nations Framework Convention on Climate Change), 2021 Process and Meetings. Accessed December 1. https://unfccc.int/processand-meetings/the-paris-agreement/nationally-determined-contributionsndcs/nationally-determined-contributions-ndcs. 


\section{ACKNOWLEDGMENTS}

This Technical Note has been produced under the International Climate Initiative (IKI). The German Federal Ministry for the Environment, Nature Conservation and Nuclear Safety (BMU) supports this initiative on the basis of a decision adopted by the German Bundestag. We would also like to thank the MacArthur Global Foundation for its support in the publication of this document.

We would like to thank WRI colleagues Apurba Mitra, Deepthi Swamy, Carlos Muñoz Pina, Ashwini Hingne, Varun Agarwal, Vishwajeet Poojary, Shahana Chattaraj, and Ulka Kelkar for their insights and suggestions that helped improve the model and this Technical Note. We are also grateful to our external reviewers Mohd. Sahil Ali (IHS Markit), Dr. Probal Ghosh (Integrated Research for Action Development), Ramya Natarajan (Centre for Science Technology and Policy) and Roberto Pasqualino (Anglia Ruskin University) for their valuable feedback, which was instrumental in the publication of this Technical Note.

We are grateful for the administrative, editorial, and design support from Renee Pinada, Emilia Suarez, Romain Warnault, LSF Editorial, and Jen Lockard.

\section{ABOUT THE AUTHORS}

Arpan Golechha is a Senior Project Associate at WRI India.

Contact: arpan.golechha@wri.org

Anisha Raman is a former Consultant-Climate Program at WRI India.

Aman Srivastava is a former Lead Economist for the Climate Program at WRI India.

Andrea M. Bassi is the Founder and CEO of KnowlEdge Srl.

Contact: andrea.bassi@ke-srl.com

Georg Pallaske is a Project Manager at KnowlEdge Srl.

Contact: georg.pallaske@ke-srl.com

\section{ABOUT WRI}

World Resources Institute is a global research organization that turns big ideas into action at the nexus of environment, economic opportunity, and human well-being.

\section{Our Challenge}

Natural resources are at the foundation of economic opportunity and human well-being. But today, we are depleting Earth's resources at rates that are not sustainable, endangering economies and people's lives. People depend on clean water, fertile land, healthy forests, and a stable climate. Livable cities and clean energy are essential for a sustainable planet. We must address these urgent, global challenges this decade.

\section{Our Vision}

We envision an equitable and prosperous planet driven by the wise management of natural resources. We aspire to create a world where the actions of government, business, and communities combine to eliminate poverty and sustain the natural environment for all people.

\section{Our Approach}

COUNT IT

We start with data. We conduct independent research and draw on the latest technology to develop new insights and recommendations. Our rigorous analysis identifies risks, unveils opportunities, and informs smart strategies. We focus our efforts on influential and emerging economies where the future of sustainability will be determined.

\section{CHANGE IT}

We use our research to influence government policies, business strategies, and civil society action. We test projects with communities, companies, and government agencies to build a strong evidence base. Then, we work with partners to deliver change on the ground that alleviates poverty and strengthens society. We hold ourselves accountable to ensure our outcomes will be bold and enduring.

\section{SCALE IT}

We don't think small. Once tested, we work with partners to adopt and expand our efforts regionally and globally. We engage with decisionmakers to carry out our ideas and elevate our impact. We measure success through government and business actions that improve people's lives and sustain a healthy environment.

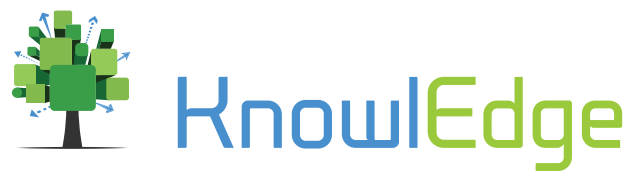

